\title{
Faces of Modernism after Trianon: Károly Kós, Lajos Kozma and Neo-Baroque Design in Interwar Hungary
}

Paul Stirton (stirton@bgc.bard.edu)

Bard Graduate Center, New York, USA

\section{Abstract}

In comparing the careers of Károly Kós and Lajos Kozma between c. 1907 and 1930, this article explores the impact of the First World War and its aftermath on the work of two leading Hungarian architect-designers. These circumstances not only affected their working practices and professional opportunities, but also reflected changes in taste, theory and the source materials of Hungarian domestic design. While Kós clung ever more desperately to the values that shaped his pre-war practice, Kozma embarked on a new direction embracing the Neo-Baroque, a style that emerged with distinctive regional characteristics in many of the successor states of Central Europe in the 1920s. The article discusses some of the sources and meanings of this style.

\section{Keywords}

Károly Kós; Lajos Kozma; Gyula Szekfü; Neo-Baroque; Transylvania; Fiatalok; Czech Cubism; folk culture; design; Hungary

https://doi.org/10.5817/AEC2021-1-2 


\section{Faces of Modernism after Trianon: Károly Kós, Lajos Kozma and Neo-Baroque Design in Interwar Hungary}

\section{Paul Stirton}

\section{Introduction}

This article compares the parallel careers of two Hungarian architect-designers, from their early success in Budapest prior to the First World War, to their contrasted fortunes in the 1920s. In presenting this material mostly as an account, rather than a thematic analysis, it is intended to provide examples of two issues in the design culture of Central Europe. The first is to highlight some of the ways in which the practice of architect-designers were transformed, directly and indirectly, by the seismic shifts in the political landscape at the end of the War. In some respects, this may seem obvious; dramatic socio-economic changes generally have a direct and immediate impact on design practice. Nevertheless, it is worth looking more closely at the ways in which external events opened up opportunities for some, while thwarting the ability to continue working in previously successful modes. The second aim is to examine the shift in taste and critical values that occurred between the pre- and post-war cultural environment, reflected here in the move from a preoccupation with rural or peasant crafts to one based upon the eighteenth-century 'folk Baroque.' Although the 'Neo-Baroque' had a considerable vogue throughout Central Europe in the 1920s, especially in the field of interior design, it remains relatively understudied by historians. In addressing this gap in scholarship, the present article seeks to bring out some of its distinctive regional and national meanings in the context of inter-war Hungary.

\section{Kós, Kozma and the vernacular revival}

The two figures to be considered are Károly Kós (1883-1977) and Lajos Kozma (1884-1948), both members of the Fiatalok (The Young Ones), a group of students who completed their training at the Architecture School of the Royal Josef Technical University (now the University of Technology and Economics) in Budapest between 1906 and 1908. ${ }^{1}$ This group produced the journal A Ház (The House, 1908-11), one of the finest Arts \& Crafts or National Romantic journals, which served as a mouthpiece for their views on the use of traditional vernacular or village sources in the creation of a Hungarian National Style (Figure 1$).^{2}$ It is well known

1) There is a considerable literature on both designers, mostly in Hungarian. Modern monographs are, Anthony Gall, Károly Kós, Budapest: Holnap Kiadó, 2019; Anthony Gall, Kós Károly mühelye / The Workshop of Károly Kós, Budapest: Mundus Kiadó, 2002; Ėva Kiss \& Hilda Horváth, Kozma Lajos, az iparművész (1884-1948), Budapest: Iparművészeti Múzeum, 1994; Éva Horányi, ed., Kozma Lajos modern épületei, Budapest: TERC Kiadó, 2006.

2) A Ház, edited by Béla Málnai and Dezső Székely, was published in Budapest in 4 volumes between 1908 and 1911. 


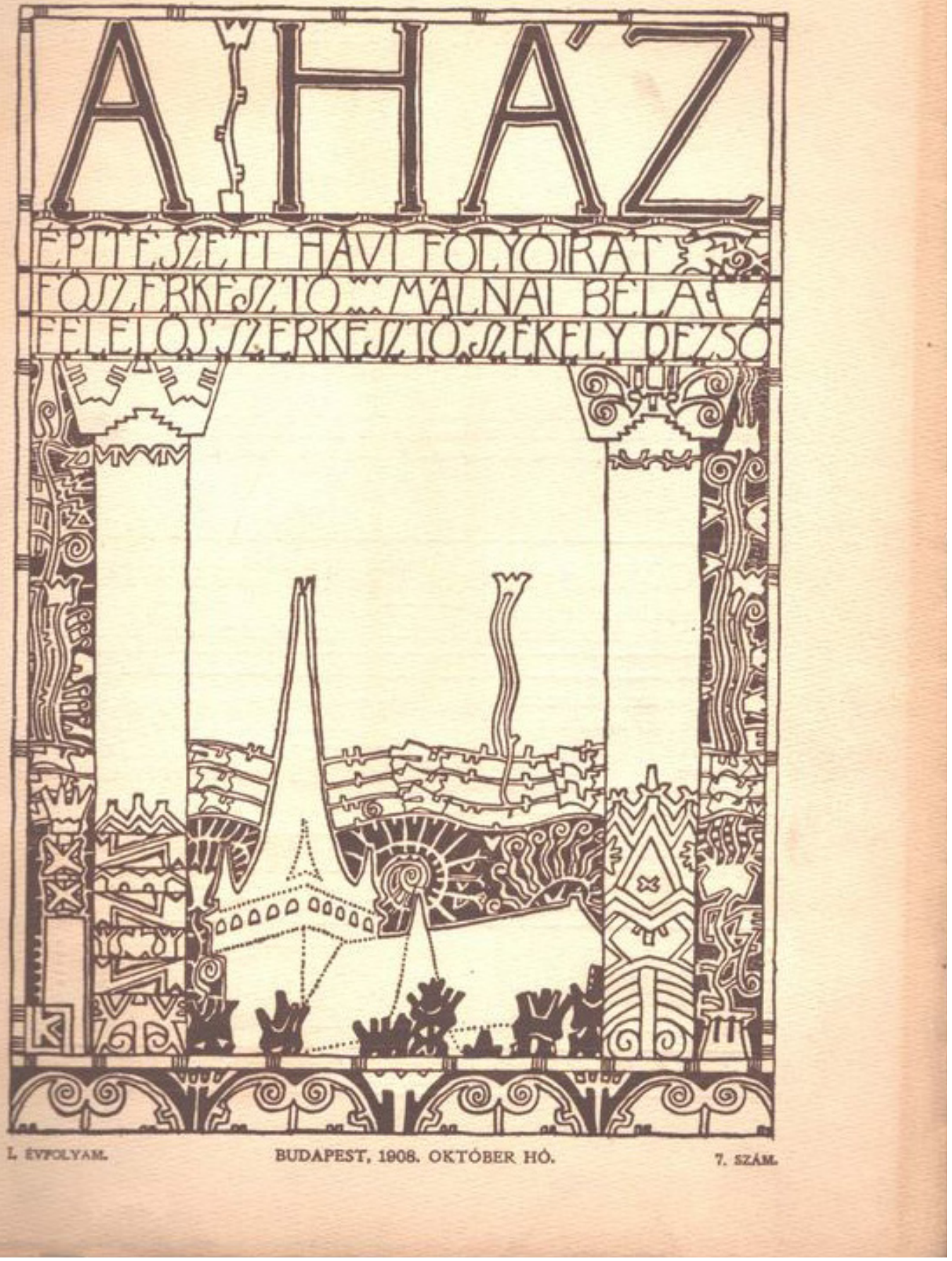

Figure 1: Cover of A Ház, 1, April 1908. Woodcut by Lajos Kozma. Source: Bard Graduate Center, New York. 
that, as with other 'smaller nations' or ethnic groups seeking to assert some form of national identity, this had been a burning issue among Hungarian architect-designers for some time before $1908 .{ }^{3}$ No less a figure than Ödön Lechner had opened a rousing article with the clarion call, 'So far, there has not been a Hungarian language of form. But there will be. Because there must be."

Many individuals and groups had already attempted to address this perceived lack of an indigenous 'language of form,' notably those at the crafts colony at Gödöllö, but there is a case to be made that the members of the Fiatalok were the most committed and the most rigorous in their search for authentic craft traditions, looking especially to the region of the Kalotaszeg in Transylvania, at that time, eastern Hungary. The Fiatalok had certain advantages over previous groups seeking inspiration in the vernacular. Above all, they had the benefit of Dezsö Malonyay's ambitious ethnographic project; fieldwork campaigns throughout the Hungarian crown lands, or Greater Hungary, which began in 1904 documenting examples of traditional crafts, interviewing villagers, and producing drawings, paintings and diagrams from their research. ${ }^{5}$ In fact, several Gödöllő and Fiatalok members participated in these information gathering projects thus ensuring a rich visual dimension when the research was published in the monumental five-volume series, A magyar nép müvészete (The Art of the Hungarian People). ${ }^{6}$

Malonyay was only the most recent, and the most conscientious, in a series of metropolitan intellectuals and curators who took an ethnographic interest in the folk arts of Greater Hungary.

The most important of his precursors was József Huszka (1854-1934), a drawing master who, in the 1880s, embarked on a series of expeditions throughout the Crown lands measuring cottages and churches, and making watercolour studies of everything he saw, from cushion embroideries to carved gateways, christening bonnets to grave posts. ${ }^{7}$ Huszka maintained a determinedly anti-historical attitude towards the folk arts, seeing this treasury as a resource of vital and meaningful forms for modern creative activity. ${ }^{8}$ It was a view that carried much weight in the decades that followed. In 1898, for example, the art critic Károly Lyka could

3) The question of 'national identity' expressed through the folk arts in Europe around 1900, and its uses by architects and musicians especially, has been the subject of numerous studies although mostly limited to a single ethnic or linguistic group. For an overview, see Nicola Gordon Bowe, ed., Art and the National Dream: the Search for Vernacular Expression in Turn-of-the-Century Design, Dublin: Irish Academic Press, 1993. For critical analyses of this movement in Central Europe, see David Crowley, 'The Uses of Peasant Design in Austria-Hungary in the Late Nineteenth and Early Twentieth Centuries,' Studies in the Decorative Arts, 2:2, Spring 1995, 2-28; Paul Stirton and Juliet Kinchin, 'The Hungarian Folk Arts Debate,' in Gyula Ernyey, ed., Britain and Hungary: Contacts in Architecture and Design, Budapest: Hungarian University of Craft and Design, 1999, 30-46.

4) Ödön Lechner, 'Magyar formanyelv nem volt, hanem lesz,' Müvészet, 1:5, 1906, 1-18.

5) After the Ausgleich of 1867, when Hungary was given nominal equal status in the Habsburg Empire, the territory of 'Greater Hungary' was known as the Lands of the Crown of St. Stephen (a Szent Korona Országai) or Lands of the Hungarian Crown (Magyar Korona Országai). As well as the territory of modern Hungary, 'Greater Hungary' incorporated Slovakia, Transylvania, and parts of modern Romania, Ukraine, Serbia, Slovenia, Austria and Poland.

6) Dezső Malonyay, A magyar nép müvészete, Budapest: Franklin-Társulat, 1907-22. Volumes 1 and 2 were devoted to the folk arts of Transylvania.

7) On Huszka, see Zoltan Fejős, ed., Huszka József: a rajzoló gyüjtő, Budapest: Néprajzi Múzeum, 2006

8) Huszka stood in opposition to the historicist views of the archaeologist Moritz von Hoernes who, on setting up the permanent ethnographic display in Vienna in 1905, placed the folk arts in a subordinate position vis-à-vis the fine arts as expressions of an earlier or 'primitive' culture. See Katalin Sinkó, 'Megjegyzések a 19. századi ornamentika-teóriák antropológiai vonatkozásairól,' in Ornamentika és modernizmus, Budapest: Ernst Múzeum, 2006, 22-24. 
write that ethnography was a historical science that 'transposes the past into the present.' In this spirit, Huszka prepared a series of worksheets with patterns and motifs to be copied as a way of mastering 'Magyar díszítő styl' (Hungarian Decorative Style) (Figure 2). ${ }^{10}$ Thus began a tradition of teaching the repertoire of folk ornament through albums of printed diagrams called 'Mintalapok' with a programme of exercises based on copying and adapting various forms and patterns. This carried on throughout the inter-war and Communist periods, encouraged by a climate of shortages in which do-it-yourself home decorating and dressmaking were common practice.

In a tendency common to radical groups seeking to outdo their predecessors, the Fiatalok were more extreme in their devotion to the folk arts, more elemental, and more thorough than many of the groups that came before them. They also developed a body of theory about the meaning and significance of the folk arts in fashioning a new visual language for both domestic and grander public design. Kós, in particular, upheld the notion that the true spirit of Magyar culture, which had achieved its highest form in the middle ages and Renaissance, had been all but wiped out by the Ottomans in the sixteenth and seventeenth centuries, and further suppressed by the Habsburgs, but that it had survived in the folk arts, especially those of Transylvania, his native region. ${ }^{11}$ This theory was not unusual in the first two decades of the twentieth century, largely informed by an idealised view of the peasantry, as if they had not been subject to the same processes of historical and cultural change that the higher classes and urban proletariat experienced. This now seems questionable, but there was certainly a theory among nationalist historians that the peasantry stood outside of mainstream history. ${ }^{12}$

For Kós, therefore, the spirit of Hungarian medieval culture and lifeways survived in the 'unchanging' village communities, and by studying them closely and faithfully one could reach back to a purer, uncorrupted well of native culture. 'Our people chose the Middle Ages as their stylistic base, and they have never abandoned it, even to this day', Kós wrote in 1907, going on to add: 'Medieval art forms the basis of Hungarian folk-art, and folk-art forms the basis of our national Art. ${ }^{13}$ These views were laced throughout A Ház, in both the articles and the illustrations, especially the woodcuts by Kós and Kozma. The distinctive profile of churches at Körösfö and Magyarvalko were particular icons of the movement, the former appearing on the title page of $A$ Ház in October 1908. This focus on a few identifiable monuments was summed up in an article on the Fiatalok by Elemér Czakó: 'All have roamed the countryside, and all have returned to Körösfö in Kalotaszeg. They have drawn houses, interiors, grave posts,

9) Ibid.

10) Huszka's book Magyar díszitő styl, Budapest: Deutsch, 1885, had 45 sheets of designs. Other publications by him on the theme of decoration and national identity include Teremtsünk igazán magyar müipart, [Let's Create a Truly Hungarian Art Industry] Sepsiszentgyörgy: 1890; 'Hazai ornamentikánk eredete és nemzetisége' [The origin and national character of our ornament] in Magyar Mérnök és Épitész Egylet Közlönye, 25, 1891, 154-67, 'Nemzeti épitészetünk múltja és jelene' [The past and present of our national architecture], in Magyar Mérnök és Épitész Egylet Közlönye, 26, 1892, 203., and Magyar Ornamentika, Budapest: Patria, 1898.

11) It is significant that Kós played down the Turanist view in which the sources of Hungarian language and culture were thought to originate in Central Asia.

12) Tanya Harrod, “ “For Love and Not For Money”: Reviving Peasant Art in Britain 1880-1930, and David Crowley, 'Haslemere and the Edges of Europe', in David Crowley and Lou Taylor, eds, The Lost Arts of Europe: The Haslemere Museum collection of European Peasant Art, Haslemere: Haslemere Educational Museum, 2000, 13-24 and 44-56.

13) Károly Kós, Erdélyország népének épitése, [Architecture of the Transylvanian People], manuscript from 1907 in National Széchényi Library, partially reprinted in A Ház, 2:1, 1909, 125-132. 

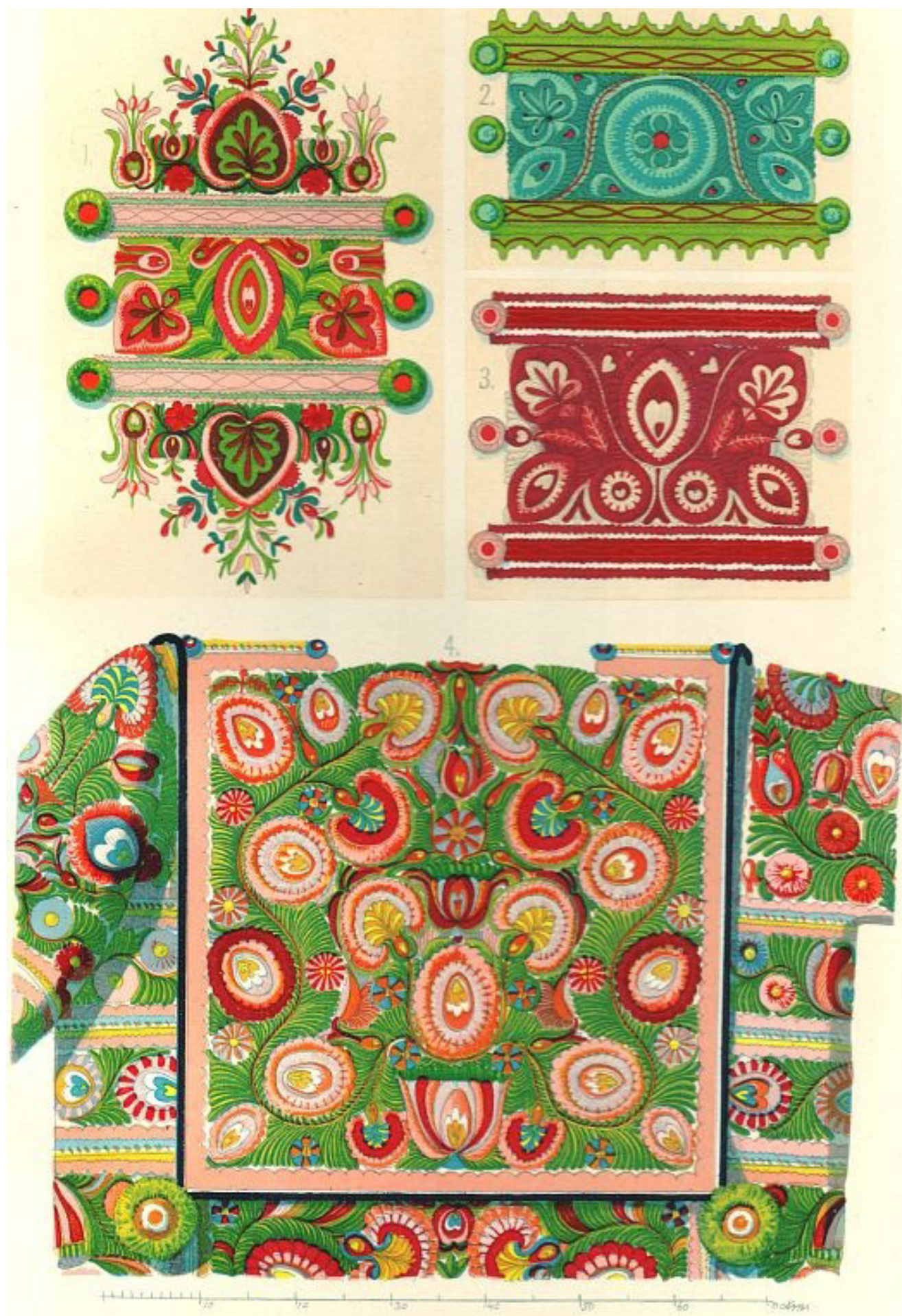

Ungarische Ornamentik. - La decoration hongroise

Figure 2: József Huszka, plates from Magyar Ornamentika, Budapest: Patria, 1898.

Photo: author. 


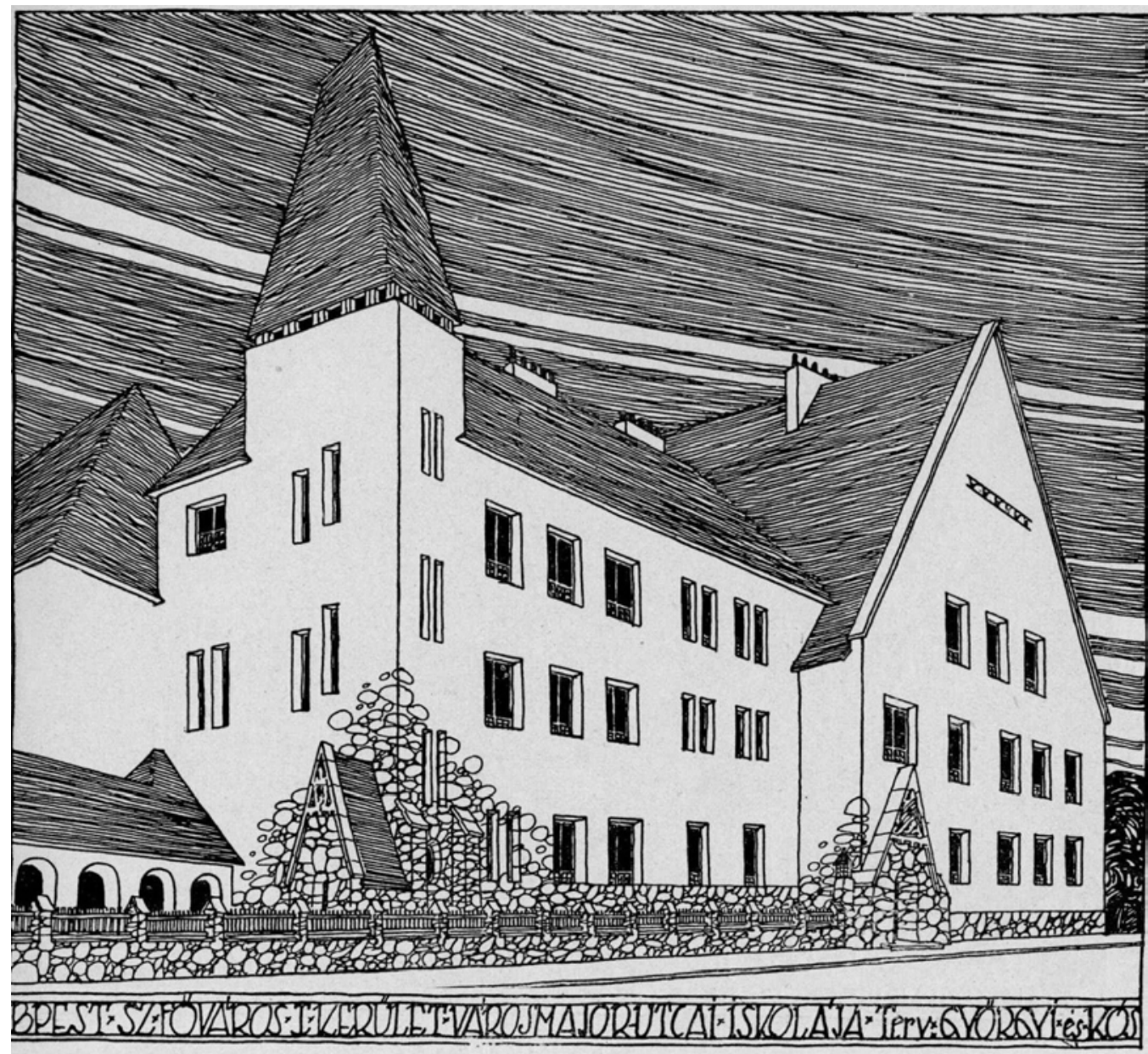

Figure 3: Károly Kós, Perspective Drawing of Primary School on Varosmajor Utca, Budapest, 1910.

Source: Magyar Építömüvészet, 10.9-10, 1912.

and embroideries, but most frequently the tower of the Körösfö church. Its sensitive lines, together with those of its four small towerlets, have become engraved upon their spirits to the extent that they regard it as the Japanese artists regard their sacred Fujiyama. ${ }^{14}$

Of the Fiatalok, Kós was, by some way, the most successful. ${ }^{15}$ Between 1907 and the outbreak of the First World War, he was responsible for the design of two churches, two schools (Figure 3), a museum, the garden suburb of Wekerle in the southern part of Budapest (Figure 4), several independent houses and a series of buildings for the animals and birds in Budapest Zoo. ${ }^{16}$ In each case, we can see elaborations of his research into the vernacular architecture and crafts of rural Hungarian communities. The Zoo buildings and Wekerle are perhaps the most dramatic examples of Kós's application of village vernacular to metropolitan building types, but the

14) Elemér Czakó, ‘Mai magyar egyházmüvészet,' Magyar Iparmüvészet, 11:3, 1908, 120-125.

15) According to Kós, the Fiatalok was a loose grouping consisting of around eight or nine members, although several others were also involved in their activities. See Károly Kós, Ėletrajz [Biography], Budapest: Kriterion Szépirodalmi, Kiadó, 1991, 55.

16) In some of these projects, notably the zoo buildings, Kós was assisted by his Fiatalok colleague Dezső Zrumeczky. 


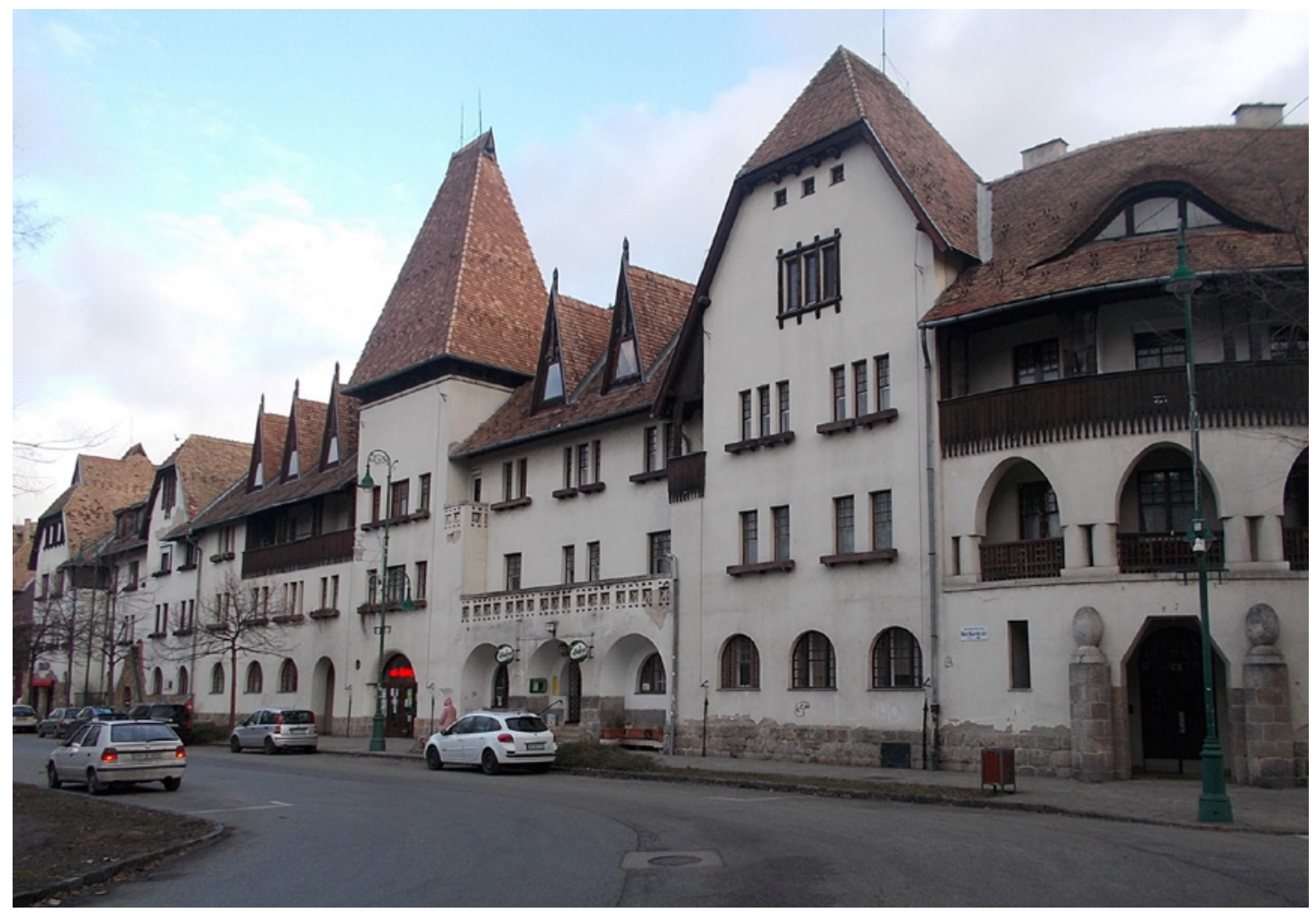

Figure 4: Károly Kós, Main square at Wekerle, designed 1912.

Photo: author.

Cock Church in Kolozsvár (now Cluj-Napoca) is the most comprehensive demonstration of his aesthetic ideals (Figure 5). In this building for a modest Calvinist parish in Transylvania, he was able to control all aspects of the design from the choice of materials and overall massing of forms down to the hand-crafted door fittings and wall lamps. ${ }^{17}$

It should be remembered that Kós was only two years out of college when he was awarded the major commissions of the zoo and the schools, and that they came from august public bodies like the Ministry of Education and Budapest City Council. It would be difficult to think of a young architect-designer who had such precocious success; perhaps only Eliel Saarinen in Finland would be comparable, and he was a friend and correspondent of Kós during these years, each believing that they were on a shared path to asserting the living presence of their regional vernacular in a modern architectural idiom. Given this success it is not surprising that Kós was able to build a studio house for himself and his family, named Crow Castle (1909-10) in the countryside near Sztana in the Kalotaszeg region of Transylvania (Figure 6). Although remote, this became his studio and the base of his operations from then on.

Kozma enjoyed some success in these years but nothing like Kós. Being Jewish may have limited his opportunities, or perhaps his commitment to the kind of National Romanticism that often came with issues of ethnic purity or religious orthodoxy - Kós was brought up

17) There was considerable literature on the Cock Church when built, cited in Gall, Kós Károly mühelye (as in n. 1), 260-271. 


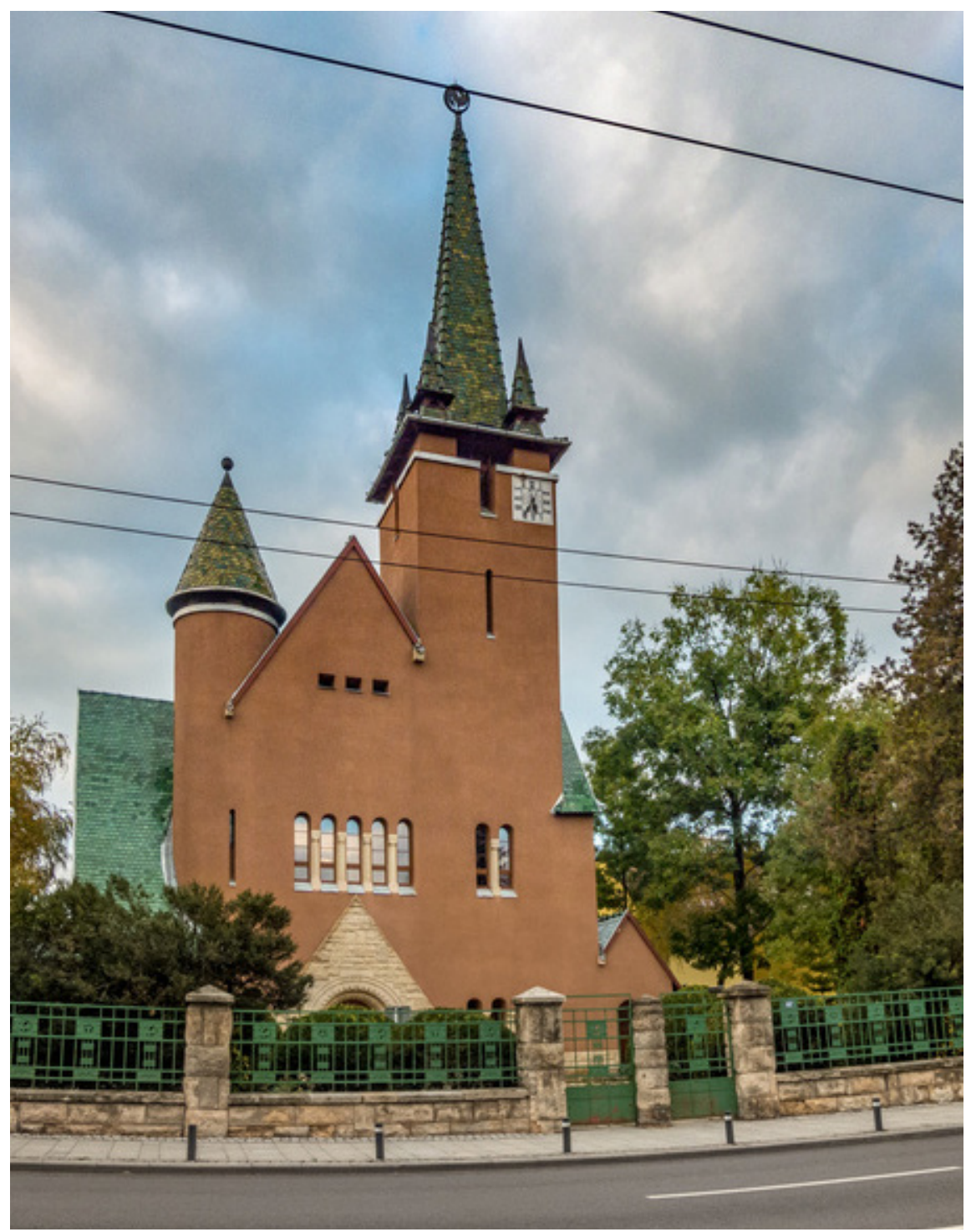

Figure 5: Károly Kós, Cock Church, Kolozsvar/Cluj Napoca, 1913-1914.

Photo: author.

a Calvinist which was regarded as the ur-religion of the Transylvanian peasantry. AntiSemitism was rife in Hungarian society, but there had been major strides in opening up the professions, banking, manufacturing and the capital investment sector under Habsburg rule. ${ }^{18}$ In these circumstances, the urban Jewish ideal of assimilation within a multi-ethnic empire could be empowering, especially in contrast to the restrictive laws that prevailed before the 1867 Ausgleich. ${ }^{19}$ There were also opportunities from within the emancipated

18) The numerus clausus, restricting the numbers of Jewish entrants to the professions was only introduced in 1920 under Admiral Horthy.

19) Kozma's family name was Fuchs, but like many others, including Lajta (formerly Leitersdorfer), he changed it to an overtly Hungarian surname, thus confirming his identification with the modern state. 


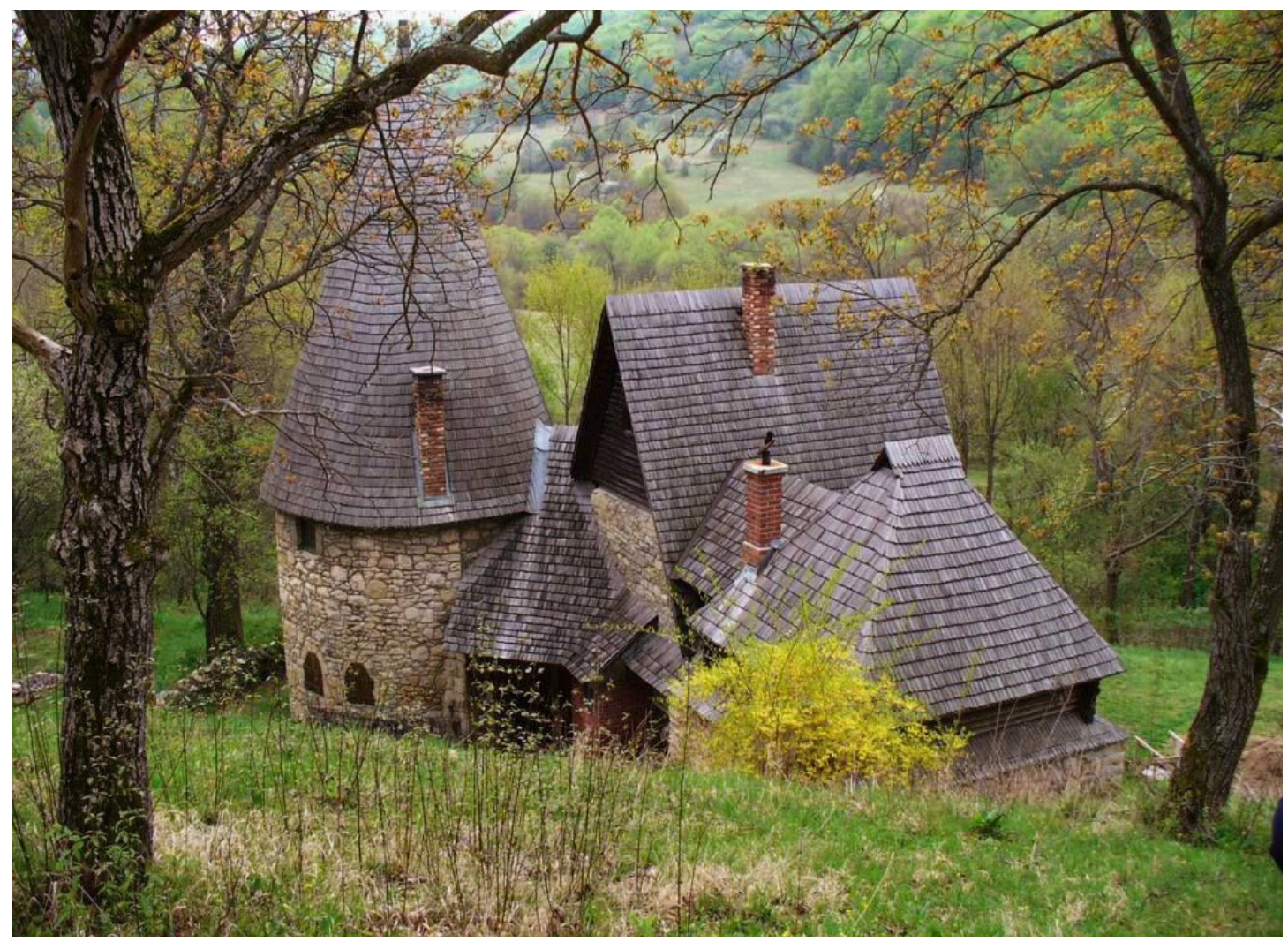

Figure 6: Károly Kós, Crow Castle, Sztana, Transylvania, 1910.

Photo: author.

Jewish middle classes who fully subscribed to the construction of a distinctive Hungarian identity in architecture and design. Between 1911 and 1913 Kozma worked in the office of Béla Lajta, whose Jewish background secured a number of major commissions, such as the Institute for the Blind (1905-08) and the Jewish Home for the Elderly (1907-11). Both these buildings are conceived in a manner inspired by vernacular building types, and employ details, particularly in the metalwork, derived from peasant chip carvings and embroideries (Figure 7).

Lajta is sometimes described as a proto-modernist, and there is some justification for this if we base these terms solely on formal values. ${ }^{20}$ The Commercial School on Vas Street (1909-12) is one of the earliest buildings in Budapest to employ the kind of stark rectilinear massing associated with the modern architecture of the 1920s and 30s, but the decorative features, notably the relief carving around the doorways, indicates the extent to which folk sources were still felt to be relevant to architect-designers who placed emphasis on abstract form and the juxtaposition of solid and void (Figure 8). ${ }^{21}$ In this case, the reliefs were again based on textile designs bearing out the widespread belief in Central Europe that textiles, especially

20) Pál Nádai, 'On a Modern Urban Builder: The Art of Béla Lajta,' in Katalin Keserü, ed., A modernizmus kezdetei/The Beginnings of Modernism in Central European Architecture, Budapest: Ernst Muzeum, 2005, 233-234

21) In Keserü, A modernizmus kezdetei, 2005, 234, the design of the carved doorway is attributed to Kozma. 


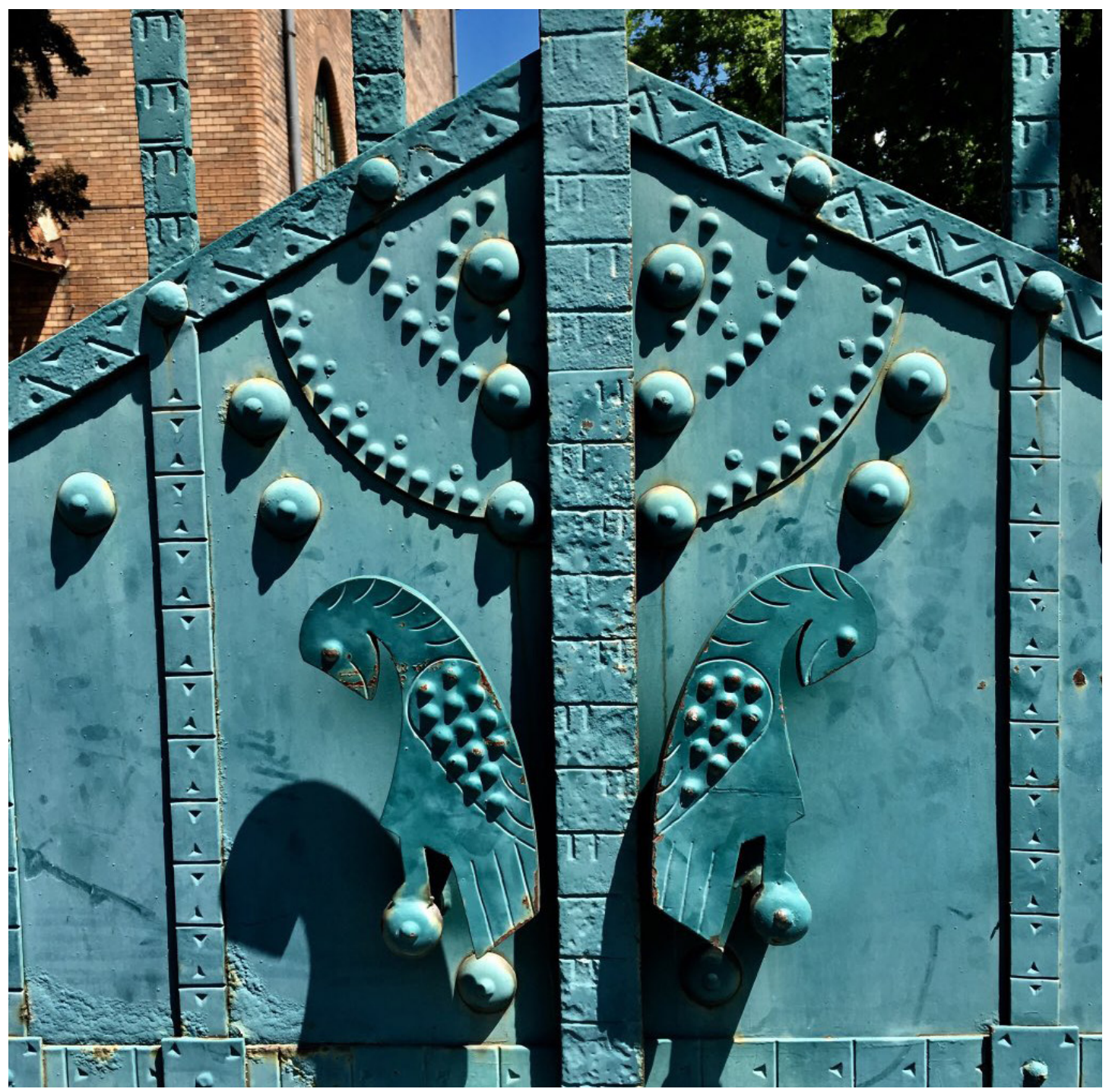

Figure 7: Béla Lajta, Metalwork detail from the Jewish Institute for the Blind, Mexikói ut, Budapest, 1908.

Photo: author.

peasant embroideries, were the most effective bearers of cultural memory and identity. ${ }^{22}$ Kozma's work for Lajta covered the full range of projects that came through the office, but he was particularly involved in designing the interiors and furniture which were, of course, planned to co-ordinate with the themes and details of the rest of the building. Kós, Kozma and Lajta were fond of 'plank' style chair forms adapted from the most basic rural prototypes, as can be seen in the furniture Kós designed for Crow Castle and which Lajta and Kozma designed for several buildings (Figure 9). In fact, the overall design, materials and construction techniques are similar in several examples across the Fiatalok, indicating the coherence of the

22) Gottfried Semper and Alois Riegl are frequently cited as the main theorists of the relationship between textiles and architecture, but the notion of textiles as repositories of national/ethnic identity had independent currency in Hungary. József Huszka, for example, cites the shepherd's overcoat (szür) as 'the ten commandments' of Hungarian style, on which 'can be read the temperament of the people.' Magyar díszitő styl, Budapest: Deutsch, $1885,46$. 


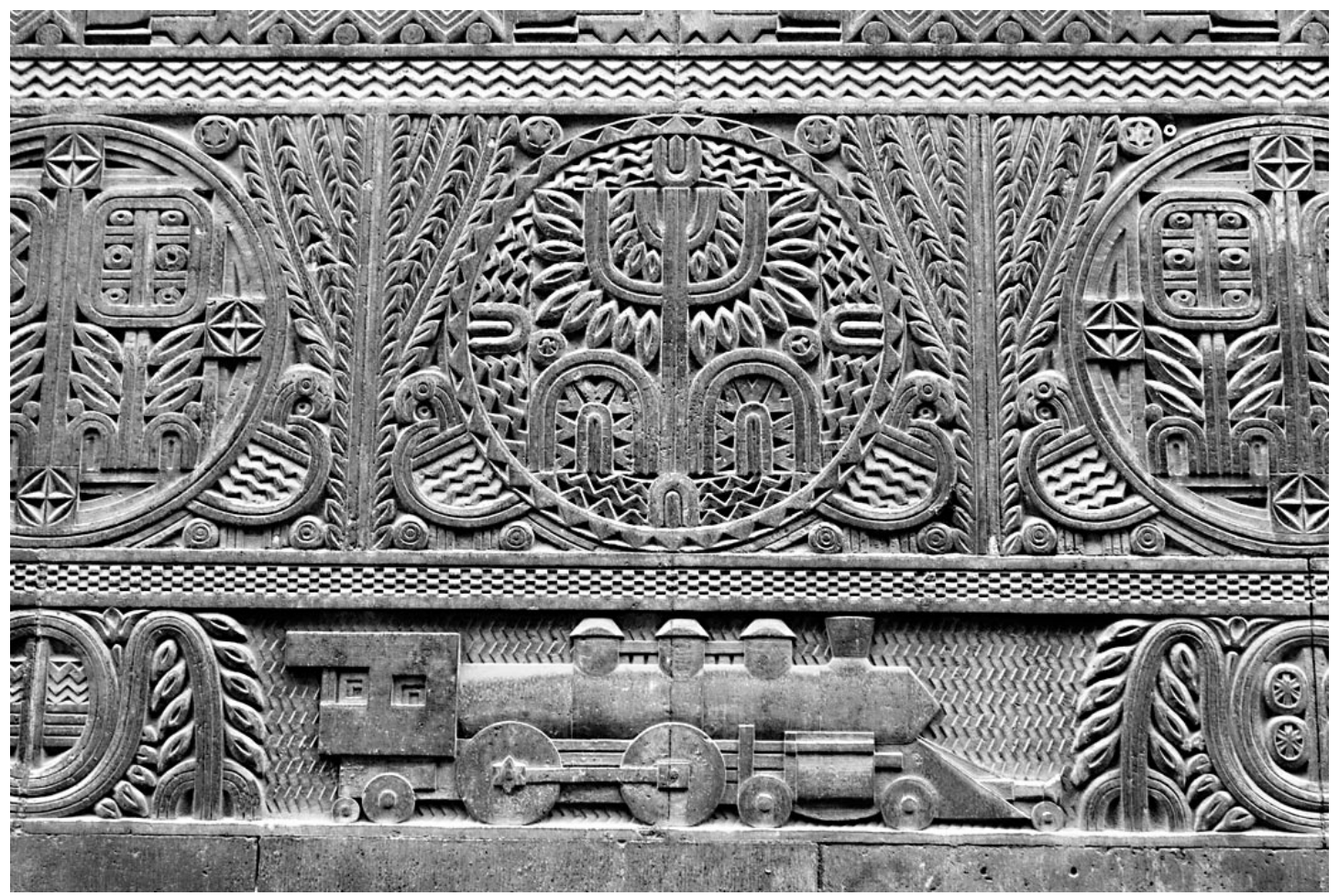

Figure 8: Lajos Kozma, Carved doorway to Commercial School in Vas Utca, 1912

group's approach to furniture design around 1910, even when intended for a variety of settings and contexts. ${ }^{23}$

In the period leading up to the First World War, however, Kozma was best known for the interior of the music shop in the so-called Rózsavölgyi-ház (Rózsavölgy shop and apartment building) in the centre of Budapest (1911-13) (Figures 10 and 11). ${ }^{24}$ This interior, and the furniture that Kozma designed for it in collaboration with the craftsmen who formed the Budapesti Mühely (Budapest Workshops), marks a definite departure from the Transylvanian vernacular that had dominated the furniture designs of the Fiatalok. ${ }^{25}$ Not only are the materials and cabinetmaking of a higher order, there is a richer and more volumetric treatment of floral and bird motifs in the carved detailing than was found on his earlier designs inspired by Transylvanian prototypes. Kozma clearly saw this as a significant moment in his own work, but also a turning point in modern design. In an article for Magyar Iparmüvészet (Hungarian Applied Art), the leading Hungarian applied arts journal of 1913 he wrote, 'We now stand at a major line demarcating the tail end of the development of modern applied arts. Looking back on two decades of work, we see the hidden flow of our aspirations - and

23) The Gödöllő designers, especially Ede Toroczkai-Wigand, also favoured plank style furniture.

24) The interior and other recent work by Kozma was published in Magyar Iparmüvészet, 16:8, 1913, 315-326.

25) The Budapesti Műhely was set up by Kozma in 1913 to reform domestic design and make a direct link between craftspeople and consumers, along the lines of the Wiener Werkstätte. The same year he also established the Budapesti Textilmüvészeti Műhelyt [Budapest Textile Art Workshop] with Klára Goldzieher and Artúr Lakatos. 


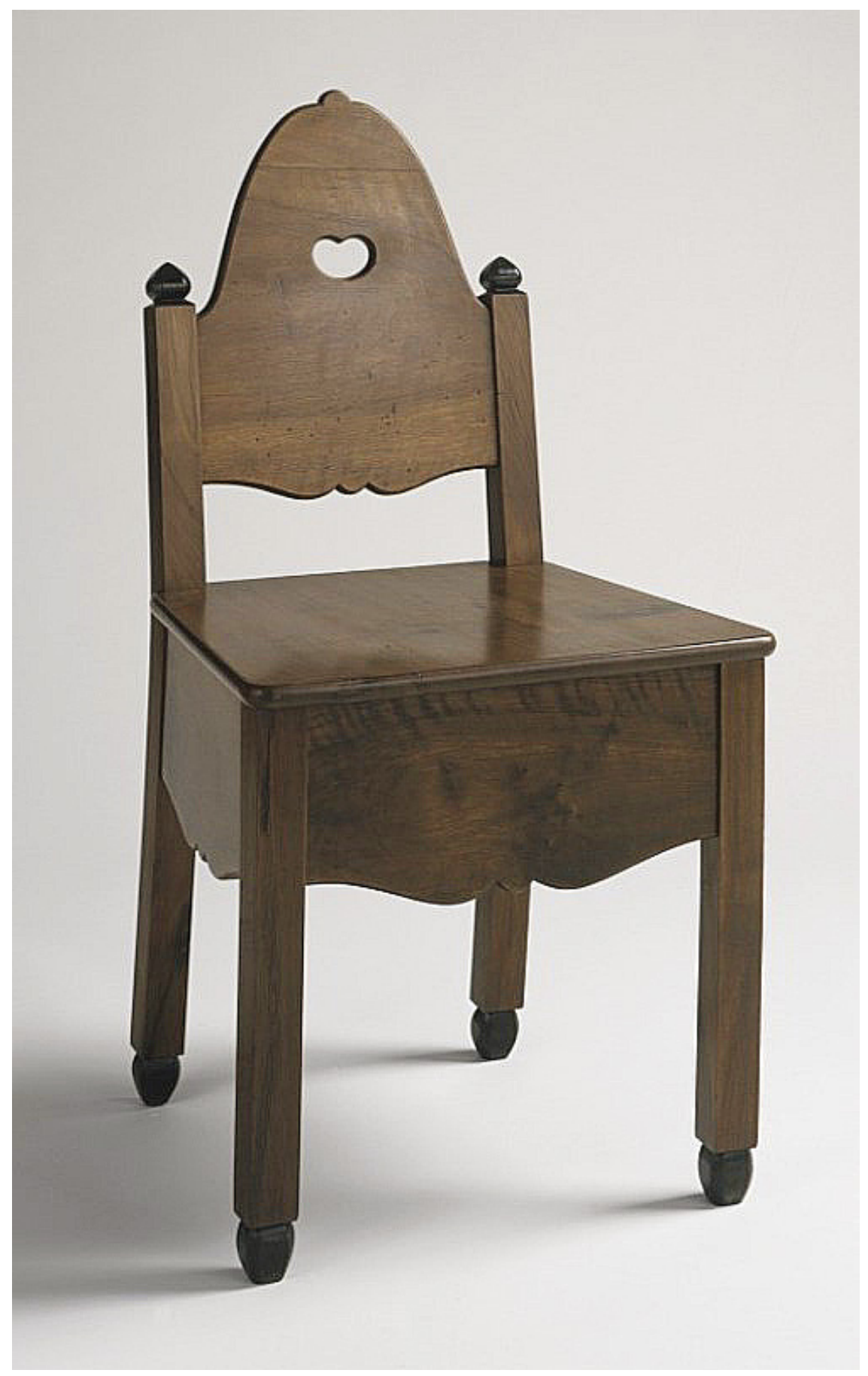

Figure 9: Károly Kós, Plank style chair for Crow Castle, c. 1920. Source: Museum of Applied Arts, Budapest. 


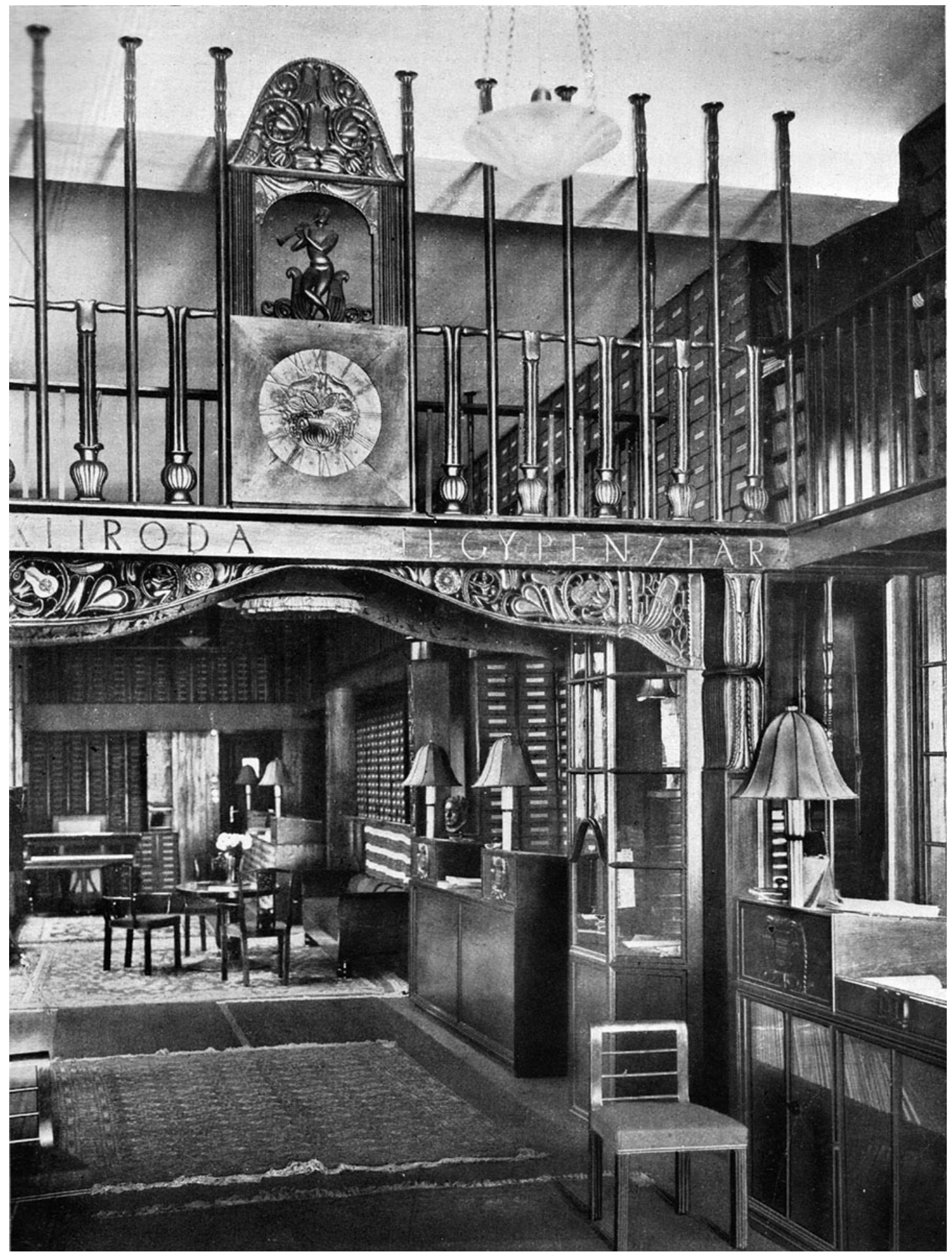

Figure 10: Lajos Kozma, Interior of the Rózsavölgyi music shop, Budapest, 1912. Source: Magyar Iparmüvészet, 16.8, 1913. 


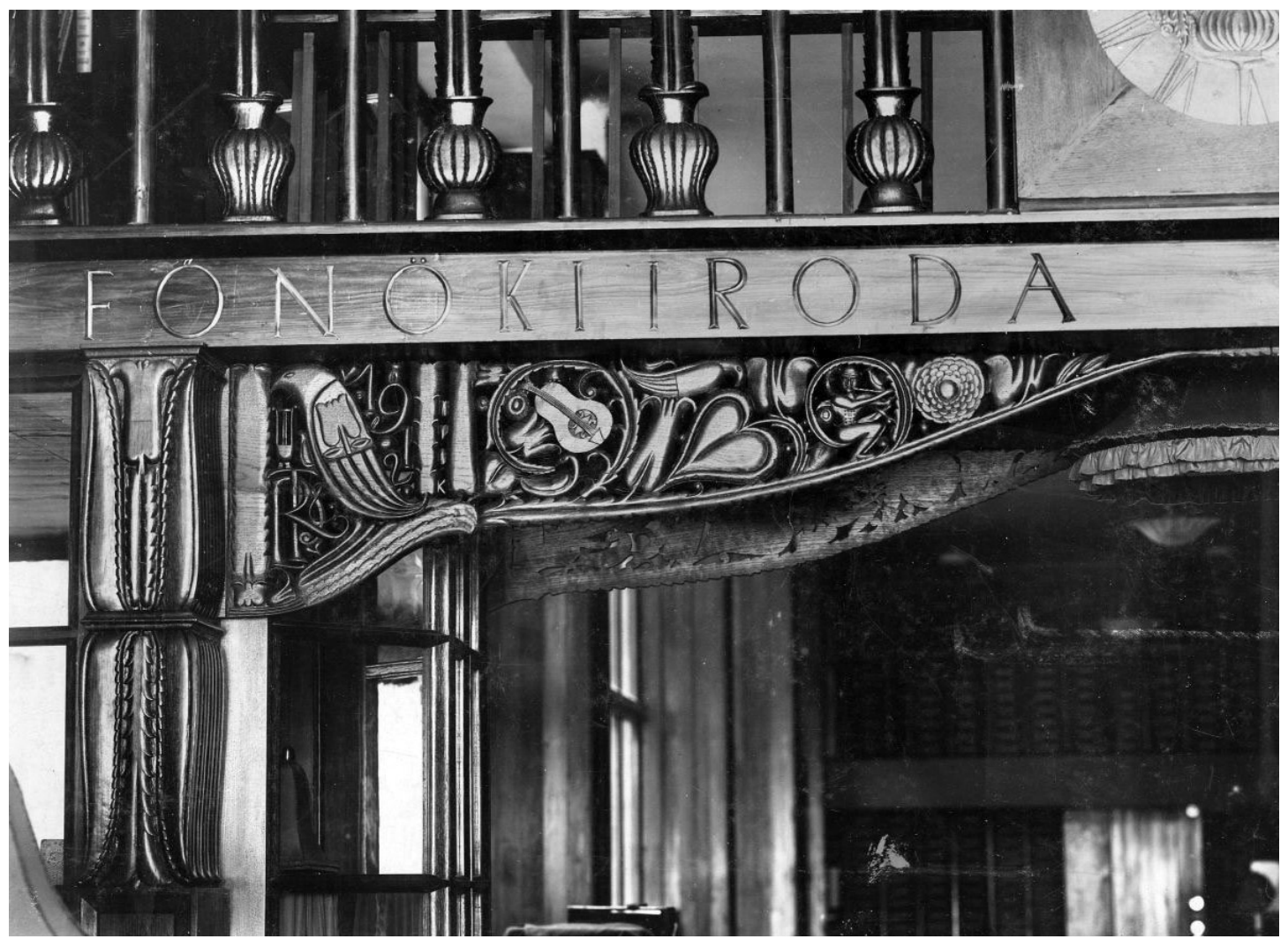

Figure 11: Lajos Kozma, Rózsavölgyi music shop, detail of carved decoration.

Source: Magyar Iparmüvészet, 16.8, 1913.

looking ahead, we can already hear the great rumbling power of the new. ${ }^{26}$ The approaching war could be seen as that 'great rumbling power,' and it would mark a definitive break in the careers of both men.

\section{The First World War and its aftermath in Hungary}

As is well known, the events at the end of the war were very different for the various national and ethnic groups of Central Europe. While the peace was marked by celebrations in the Czech, Slovak and Romanian lands, it was mourned as a disaster by those on the losing side, especially the Hungarians for whom it inaugurated a period of unprecedented political turmoil. The period between 1918 and 1919 alone, witnessed four regime changes: in November 1918, a liberal government under Mihály Károlyi replaced the Habsburg monarchy. Five months later, in March 1919, Károlyi's government was overthrown by a communist revolution led by Béla Kun which, in turn, lasted only four months before invasion and occupation by foreign powers. This was followed by a right-wing counter-revolution led by Admiral Horthy

26) Kozma Lajos, 'Az iparmüvészet fejlődésének új irányáról' [On the new trend In the development of applied arts], Magyar Iparmüvészet, 16:8, 1913, 307. 
and a reign of terror that was waged against political opponents lasting until 1921. Finally, the Treaty of Trianon, signed in June 1920 and enacted the following year, dismembered Greater Hungary, reducing it to just over one third of its former size, and its population by an equivalent amount. As a consequence, there were massive population movements as the dispersed ethnic groups crossed the redrawn borders to rejoin their compatriots. This was particularly marked in Hungary, where many ethnic Magyars fled from the successor states to the rump of a much-reduced state. These measures created a powerful sense of injustice in Hungary and a corresponding clamour for 'revanchism' that dominated Hungarian domestic politics and foreign policy, as well as a massive amount of propaganda, throughout the inter-war period (Figure 12).

How did the two architect-designers fare in this? During the war Kós continued to work on a number of projects, including the decorations for Charles IV's coronation in Budapest in 1916. But most building was suspended, and he tended to concentrate on his prints and illustrated books. In 1917 Kós moved to Turkey to supervise the building of a 'Hungarian Institute' in Istanbul, remaining there for the duration of the war. Kozma served in the artillery at the Balkan and Italian fronts, and it was there that he produced the first designs for a children's book, written for his daughter, that points towards the direction his work would take in peacetime. This book was eventually published in 1921 with the title Zsuzsa Bergengóciában (Susie in Fairyland) (Figure 13). ${ }^{27}$ The drawings are wildly extravagant depictions of a fantasy Baroque in which the small but sturdy Zsuzsa wanders through grand halls and up staircases that, while employing the familiar repertoire of high Baroque ornament, are reminiscent more of theatrical sets than actual buildings. This was not merely an exercise in fantasy book illustration. Kozma was rehearsing the decorative vocabulary of a new style of domestic design that would dominate his interiors for the next decade, translating the Baroque and Rococo into extravagantly camp and performative settings for the middle-class home.

\section{Kozma-Baroque}

The finest, or most comprehensive example of this new manner was the woman's dressing room of 1924 (Figure 14). ${ }^{28}$ This was the most theatrical of Kozma's interiors of the 1920s, partly because he was able to control the design, decoration and lighting of the entire space, creating a stage-like setting on which the client could perform her dressing and toilet. One cabinet, or variant of the pieces seen in the dressing room, survives in the Wolfsonian collection in Miami (Figure 15). ${ }^{29}$ Made of ebonized walnut and constructed using the refined techniques of eighteenth-century cabinetmakers, this sophisticated and luxurious piece of furniture seems a far cry from the self-consciously crude, pre-war plank-style chairs of the Fiatalok. ${ }^{30}$ Not only does it

27) Lajos Kozma, Zsuzsa Bergengóciában, Budapest: Sacelláry, 1921, in a limited edition of 500 copies.

28) Möbel und Raumkunst von Ludwig Kozma, Leipzig/Vienna: Friedrich Ernst Hübsch Verlag, 1926. Also published in Innen-Dekoration, 35:1, 1924, 9. The interior has not been traced so may have existed since c. 1920.

29) See the detailed analysis of this piece in Juliet Kinchin, 'Modernity and Tradition in Hungarian Furniture, 19001938: Three Generations,' The Journal of Decorative and Propaganda Arts, 24, 2002, 64-93.

30) There is a similar 'perfume cabinet' by Kozma in the Iparművészeti Múzeum, but with a varnished walnut finish. See Figure 17. 


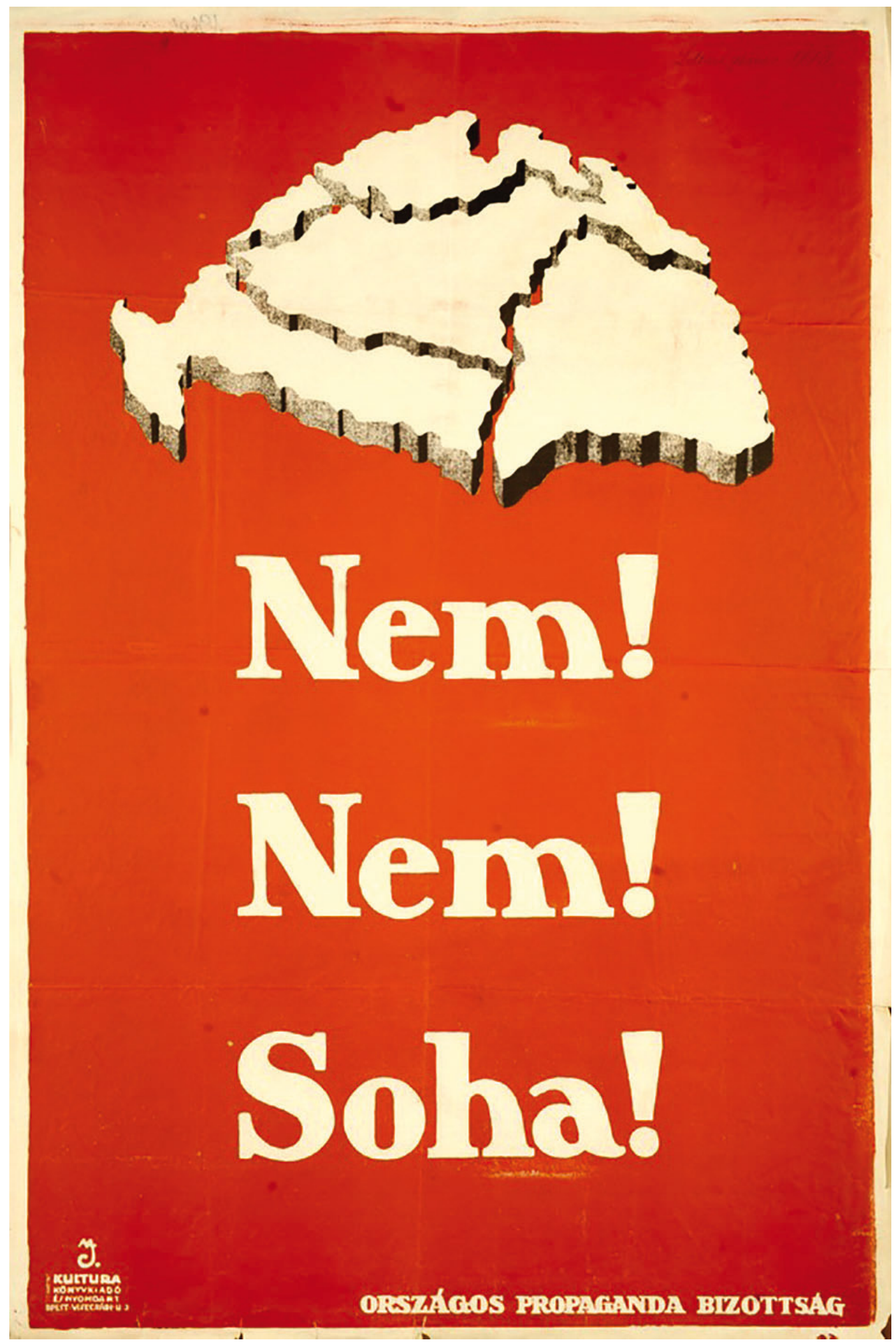

Figure 12: 'Nem, Nem, Soha' (No, No, Never). Hungarian irredentist propaganda against the terms of the Treaty of Trianon, 1920.

Photo: author. 

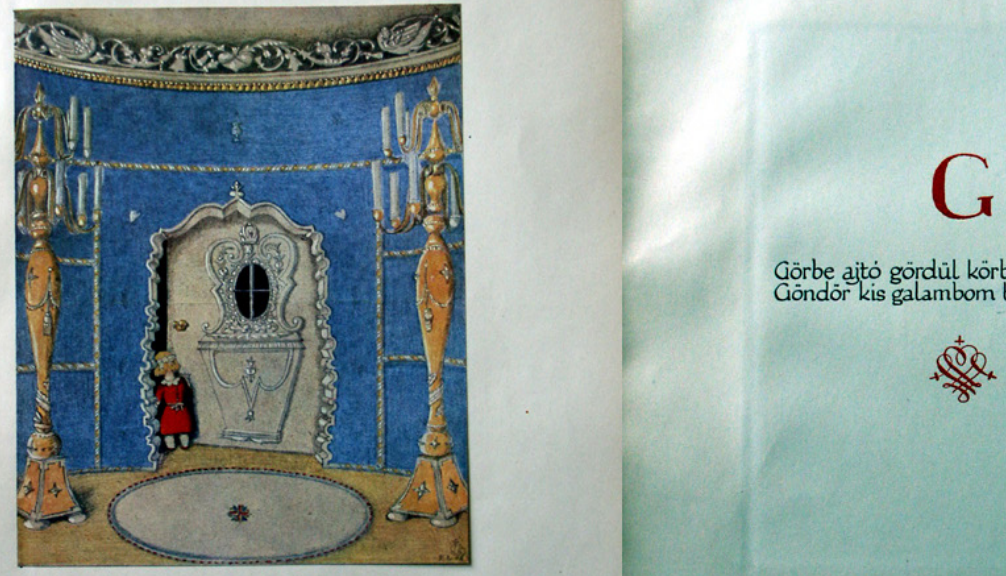

Görbe ajitó gördül körbe kéremásson. Göndör kis galambom befér a nyilàson.

Figure 13: Lajos Kozma, ' $G$ - the curved door rolls open on request. My curly little pigeon fits into the opening.' Illustration from Zsuzsa Bergengóciában [Susie in Fairyland], Budapest 1921.

Source: author's collection.

display the formal vocabulary of the Baroque and Rococo, with all their courtly associations; the historical references are further overlaid by a curious range of expressive psychological qualities. As one commentator noted, 'In the apartment there are distinctively shaped pieces of furniture, in different colours, which look to us like animated figures ... just as close relatives bring fresh life into the family circle with their individual quirks of character, so the differences (in the furniture) introduce an elegant vitality into the unity of the room. ${ }^{31}$ One could go further and attribute insect-like qualities to the shiny black object, its polished outer surface like a carapace and its legs primed for scuttling movement. The carved decoration is especially refined, closely following the motifs that Kozma was employing at the same time in his graphics.

Working with the publisher Imre Kner at the end of the war, Kozma had begun studying examples of eighteenth-century fine printing to develop a house style or corporate identity for Kner's firm..$^{32}$ This first emerged in a number of individual books at the end of the war, but it was in the various literary series, 'Kner Klasszikusok' (Kner Classics) and 'Monumenta Literarum', that the full impact of Kozma's design innovations would become apparent. Rejecting the standard cuts available from German foundries, Kozma designed a series of

31) Jenő Mohácsi, ‘Das Schlafgemach einer Dame,' Innen-Dekoration, 35:1, Jan. 1924, 6.

32) Kozma's book and graphic designs deserve an article on their own, but for information see György Haiman and Botondné Lévay, eds, A Kner-nyomda, kiadványainak tükrében 1882-1944, Budapest: Akadémiai Kiadó, 1982, 2 volumes, and György Haiman, 'Imre Kner and the Revival of Hungarian Printing,' Design Issues, 7:2, Spring 1991, 41-53. In addition to his work on their books and publicity, Kozma designed a house for Imre Kner in 1925 at Gyoma in a NeoBaroque style. 


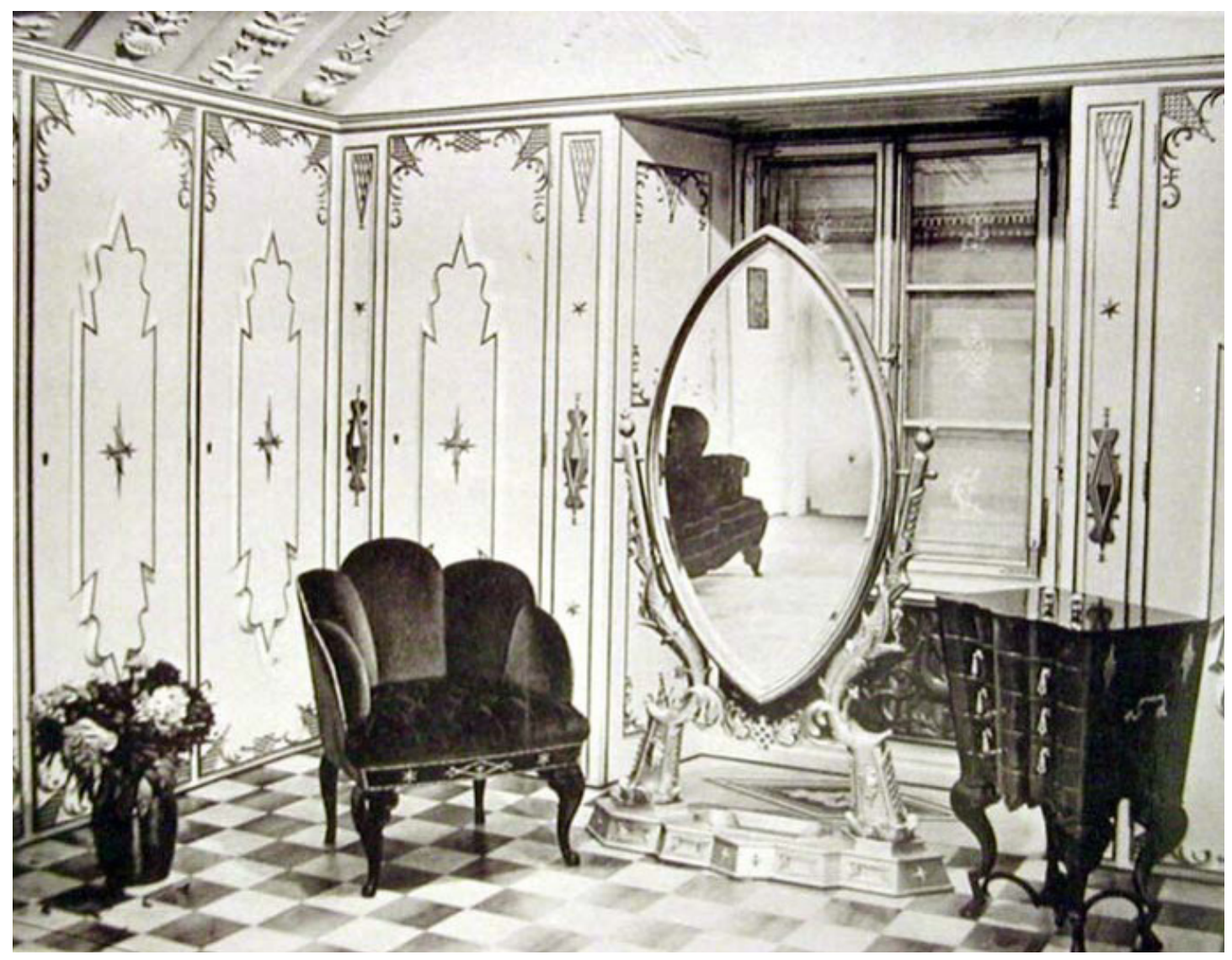

Figure 14: Lajos Kozma, Woman's dressing room, Budapest, 1924.

Source: Innen-Dekoration, 35.1, 1924.

richly ornate borders, initial letters, vignettes and tailpieces that were cut by Hungarian engravers to complement the old typefaces that Imre Kner selected (Figure 16). Kner was a connoisseur of fine printing and a close friend of the arch-modernist Jan Tschichold, but he departed from his German counterpart in his views on modern typography, believing that a high point of clarity and elegance had been achieved two centuries earlier and that the modern book designer should continue to use letterforms, layouts and ornaments that were proven to delight the reader without straining the legibility of the text. ${ }^{33}$ Kozma's designs struck a similar balance between history and contemporaneity. As one critic wrote in 1927, 'The Baroque spirit of his art is not a simple variation of the stylistic elements of the Baroque: his whole artistic career is a rigorous opposition to the cult of historic styles. [Kozma] creates his own style. ${ }^{34}$

Throughout the 1920s, Kner's books maintained high editorial and print standards, while setting contemporary and historic literature within the context of Kozma's Neo-Baroque ornaments. It quickly caught on and other publishing houses produced similar lines of gift

33) On Kner and Tschichold, see Paul Stirton, Jan Tschichold and the New Typography, New Haven: Yale University Press, 2019, 175, and Christopher Burke, Active Literature: Jan Tschichold and New Typography, London: Hyphen Press, 2007.

34) András Komor, 'Lajos Kozma,' Magyar Iparmüvészet, 15:1, 1927, 23. 


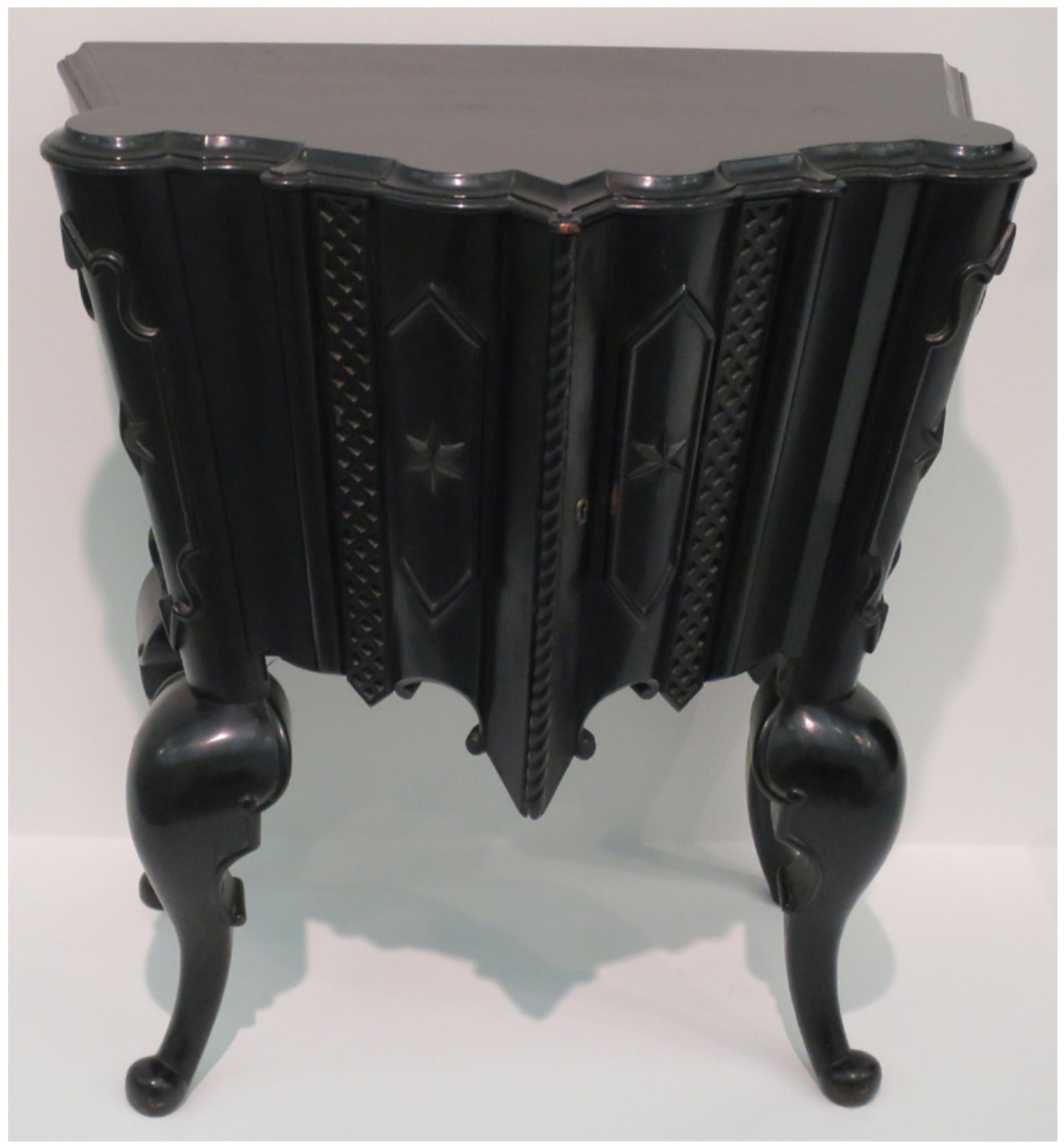

Figure 15: Lajos Kozma, Cabinet in ebonized walnut, 1923. Source: Wolfsonian-FIU Museum, Miami. 


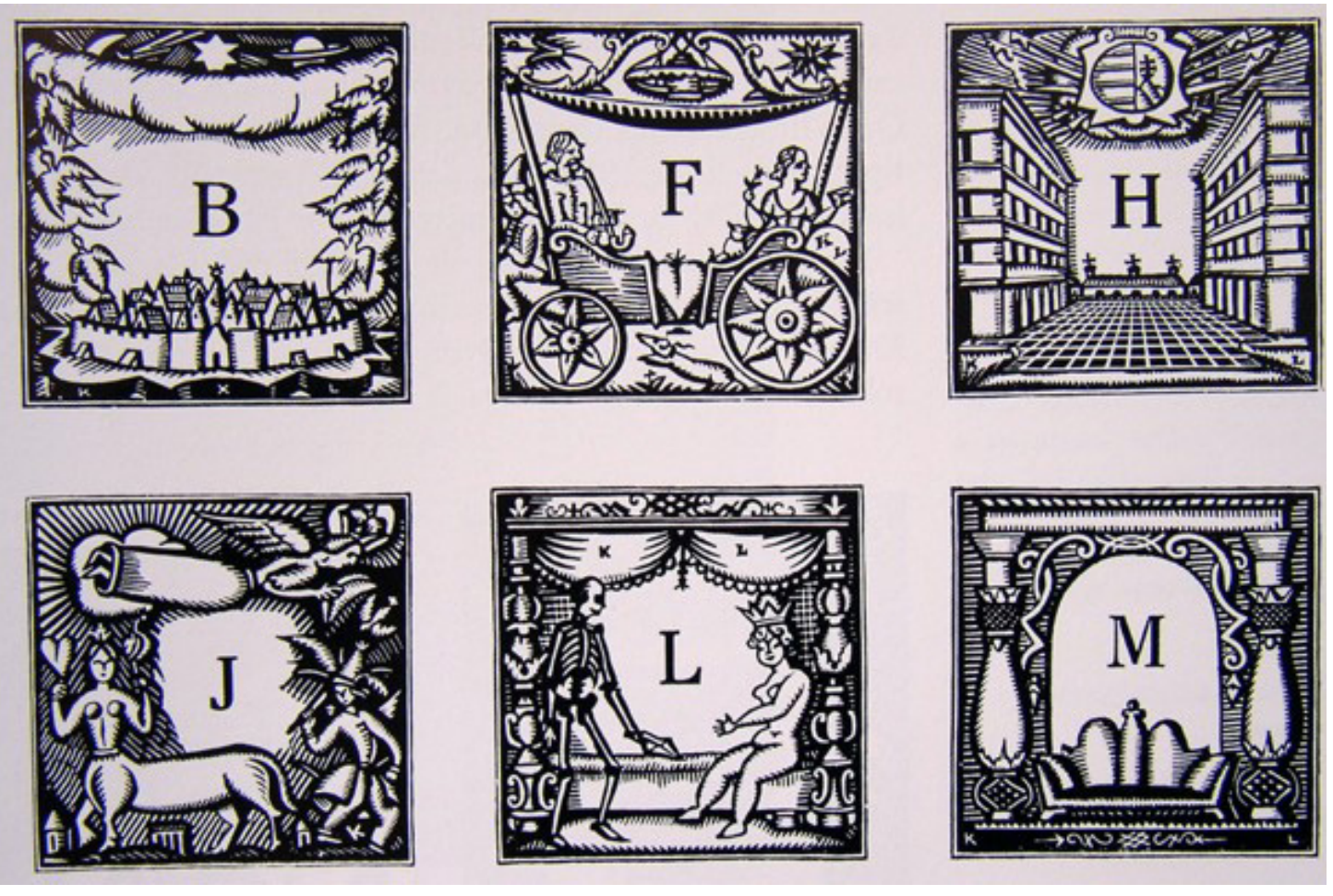

Figure 16: Lajos Kozma, Initial letters for Kner publishers, c, 1921.

Photo: author.

books in their lists, although rarely achieving the design or presswork standards of Kner. Writing in the Kner Almanach of 1922, Kozma described the character and appeal of his sources in a manner that reveals something of the possibilities that the new repertoire offered a designer: 'Rather than animation, restlessness and what is finished, it is preparation, the growth of life, fever, the driving force which finds delight in flashes of lightning, as in the burgeoning growth of fleshy tendrils; in short the dynamic power of portrayal which is fundamentally related to Baroque ornament. ${ }^{35}$ The print ornaments that Kozma designed for Kner are repeated in the carved details of the Wolfsonian cabinet and throughout the interior of the woman's dressing room, as well as countless other pieces of furniture from the 1920s, recreating that sense of a consistent but endlessly variable design vocabulary that is associated with the Baroque and Rococo.

For commercial purposes, Kozma was able to develop this repertoire in collaboration with various furniture manufacturers since it did not require the entire Gesamtkunstwerk of a coordinated interior. Individual pieces of furniture could as easily be designed and marketed to furnish specific rooms in the middle-class home. In fact, the style enjoyed considerable popularity in Hungary in the 1920s, coming to be known generically as the 'Kozma Baroque.' Chairs, beds, wardrobes, cabinets, book cases, mirrors, even domestic altarpieces were produced in significant numbers, often employing intense colours or exaggerations of scale

35) Lajos Kozma, 'Individuality and Traditions,' in Kner Almanach az 1922, Gyoma: Kner, 1922, quoted in Haiman, 'Imre Kner and the Revival of Hungarian Printing,' 45. 
that served to emphasize the playful, witty elaboration of the historic motifs in a distinctively contemporary manner for the middle class consumer (Figures 17, 18 and 19). ${ }^{36}$ Kozma also attracted followers from among the furniture and interior design community, partly through his teaching at the School of Applied Arts in Budapest, giving the Neo-Baroque the appearance of a movement rather than the singular expression of one man. ${ }^{37}$ Despite its popularity in the market, however, the style did not attract much comment in Budapest. Kozma's work received much more attention in Austria and Germany, notably in the pages of Innen-Dekoration and Deutsche Kunst und Dekoration, published in Darmstadt by Alexander Koch, or through the books of the Stuttgart publisher Julius Hoffmann. Towards the end of the 1920s, Hungarian critics began to recognise this development as a new and positive departure from the 'Transylvanian' vernacular of the pre-war period..$^{38}$ As Gyula Háy commented in 1929, 'The style that Lajos Kozma and his group appear to be reviving never in fact existed. They are doing considerably more than throwing over the existing style; they are producing something brand new, meanwhile employing historic features. ${ }^{39}$

The discourse surrounding the revival of this style at the time was not based upon its bourgeois appeal, its playfulness, or its theatricality, but on its reinterpretation of an indigenous folk tradition that was widespread in Central Europe in the seventeenth and eighteenth centuries. This was the so-called 'folk-Baroque' or 'gentry Baroque,' the building and decorative style favoured by the rural gentry that had trickled down from the court to various provincial centres. For Hungarians the most important feature of the style was that it recalled the distributed Magyar culture of the early Habsburg period, a time when Budapest was a backwater and the more modest rural landowning classes upheld a high standard of education and culture in their libraries, manor houses and furniture. A key to this link can be found in Kozma's first mature version of the so-called 'Mesélö Szék' or storyteller's chair designed for a school in 1914, which was based on an armchair owned and possibly made by the eighteenth century general and national hero Ferenc Rákóczi (1676-1735). ${ }^{40}$ What KozmaBaroque offered, therefore, was not a rejection of historic folk sources as the raw material of the national style, but rather a transfer of allegiance within that debate to a different set of sources that could claim an equivalent degree of prestige or legitimacy in the expression of modern Hungarian culture. Even Kós, although wedded to the Transylvanian vernacular, acknowledged the validity of this source. Discussing the designs for a house in Kolozsvár in 1921, he affirmed the view that there was a specifically Transylvanian Baroque. 'It came from Vienna, through Budapest and then to us. The Viennese Baroque of Maria Teresa's time is no longer the same as the Italian, the French. The Hungarian was simplified. And as it came

36) In 2018, marking the $70^{\text {th }}$ anniversary of Kozma's death, an exhibition on this subject was held at the Mücsarnok in Budapest under the title Kozma Klasszik: A Budapesti Mühely és Kozma Lajos [Classic Kozma: The Budapest Workshops and Lajos Kozma].

37) The leading interior designers in Budapest working in this manner were József Gróf, Ödön Dankó, Pál Fábry, and Kozma's student Gyula Kaesz.

38) Pál Nádai was just about the only critic to write seriously on 'Kozma-Baroque, in the early 1920 s. See his $A z$ iparmüvészet Magyarországon [Applied Arts in Hungary], Budapest: Biró Miklós Kiadása, 1920

39) Gyula Háy, 'Kozma Lajos, ahogy ma látjuk' [Lajos Kozma as we see him today], Tér és Forma, 2:7, 1929, 278-287.

40) The Mesélő Szék was shown at the Children's exhibition in the Budapesti Műhely, 1914, and discussed by Pál Nádai in the article 'Gyermekművészet’ [Childrens' Art], Magyar Iparművészet, 17, 1914, 219 and 237-240. Rákóczi’s armchair had been exhibited in Budapest and Košice in 1906 at the time of the hero's reburial in Hungary. 


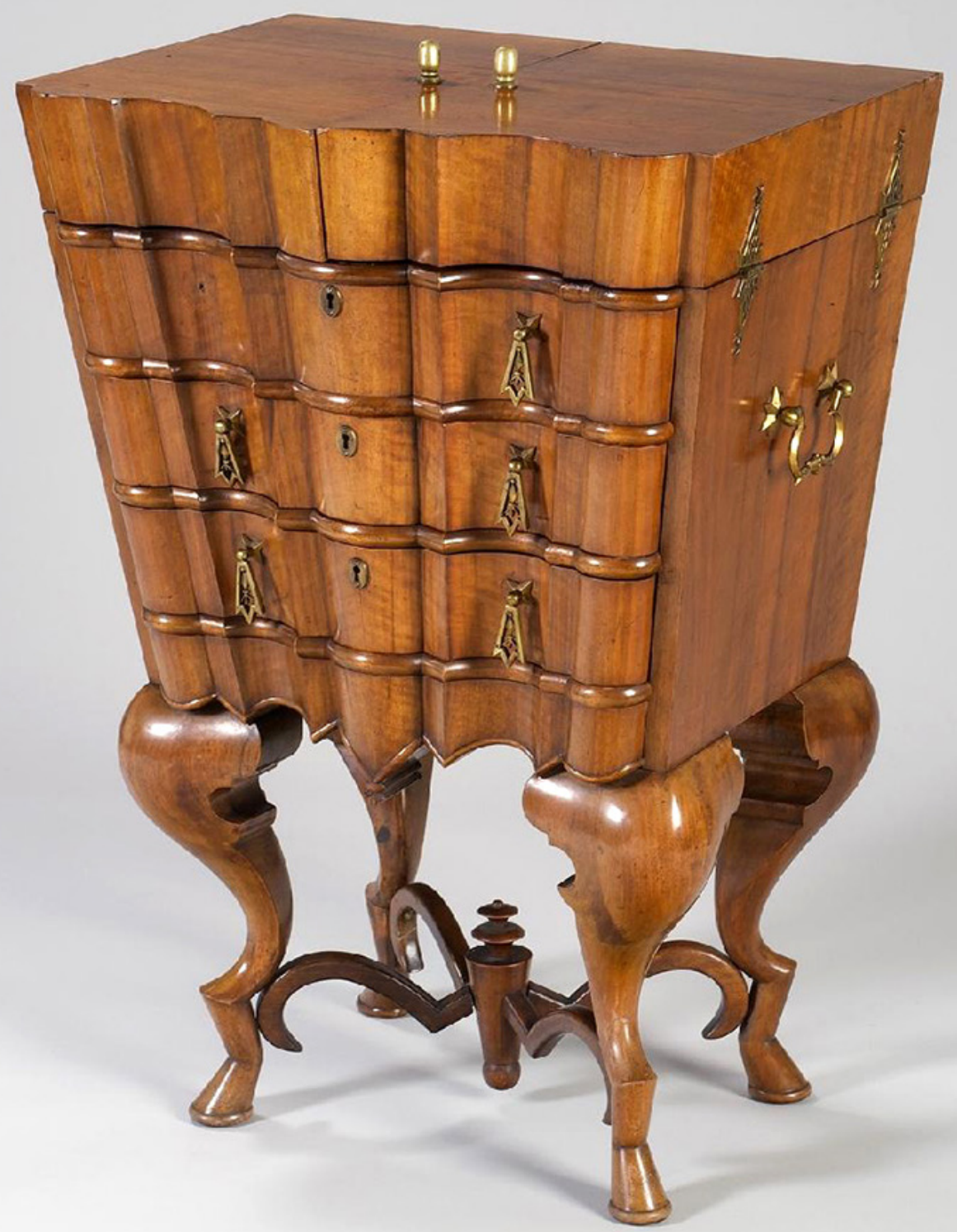

Figure 17: Lajos Kozma, Perfume Cabinet in walnut, c. 1923.

Source: Museum of Applied Arts, Budapest. 


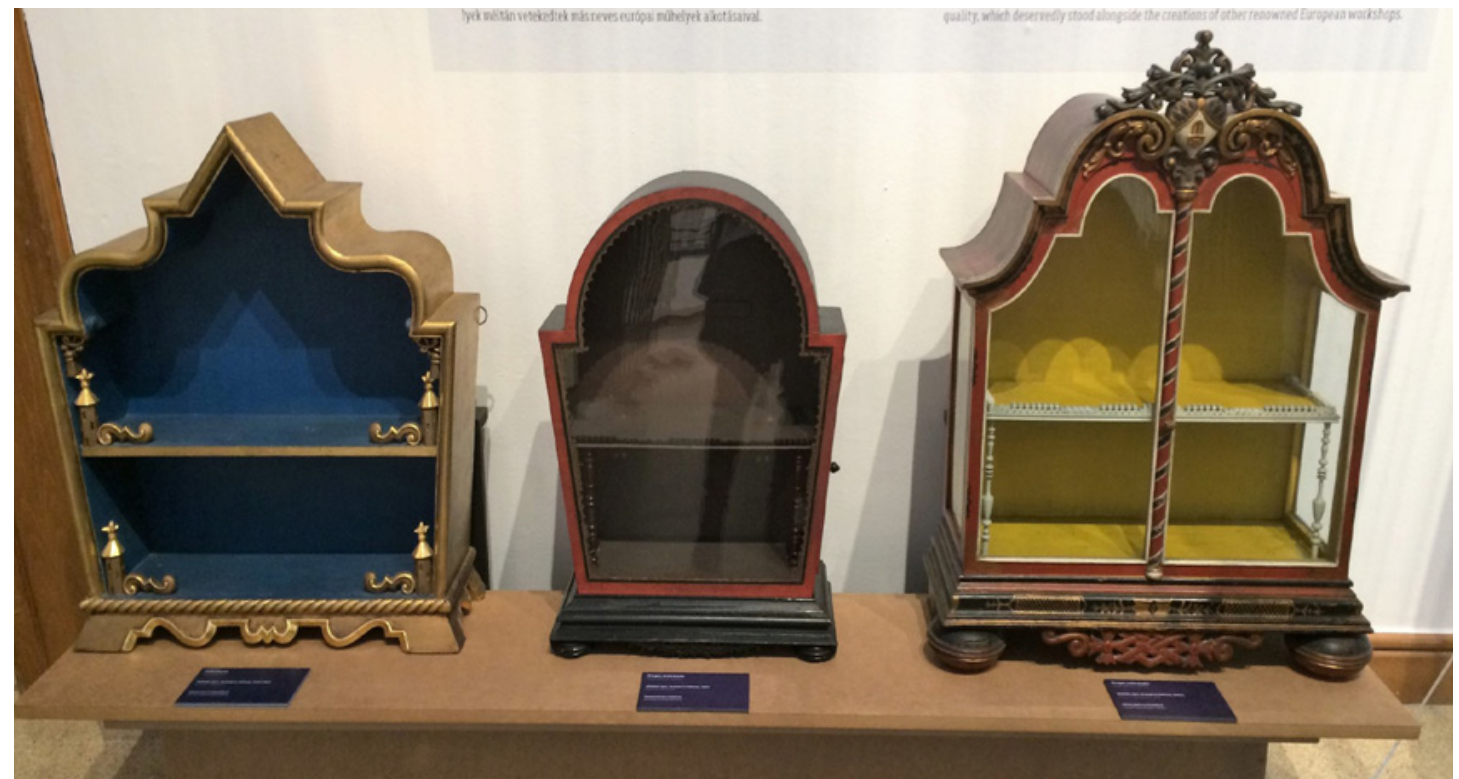

Figure 18: Lajos Kozma, Display cabinets, c. 1924 as displayed in exhibition 'Kozma Klasszik: a Budapesti Mühely és Lajos Kozma,' Mücsarnok, Budapest, 2018.

Photo: author.

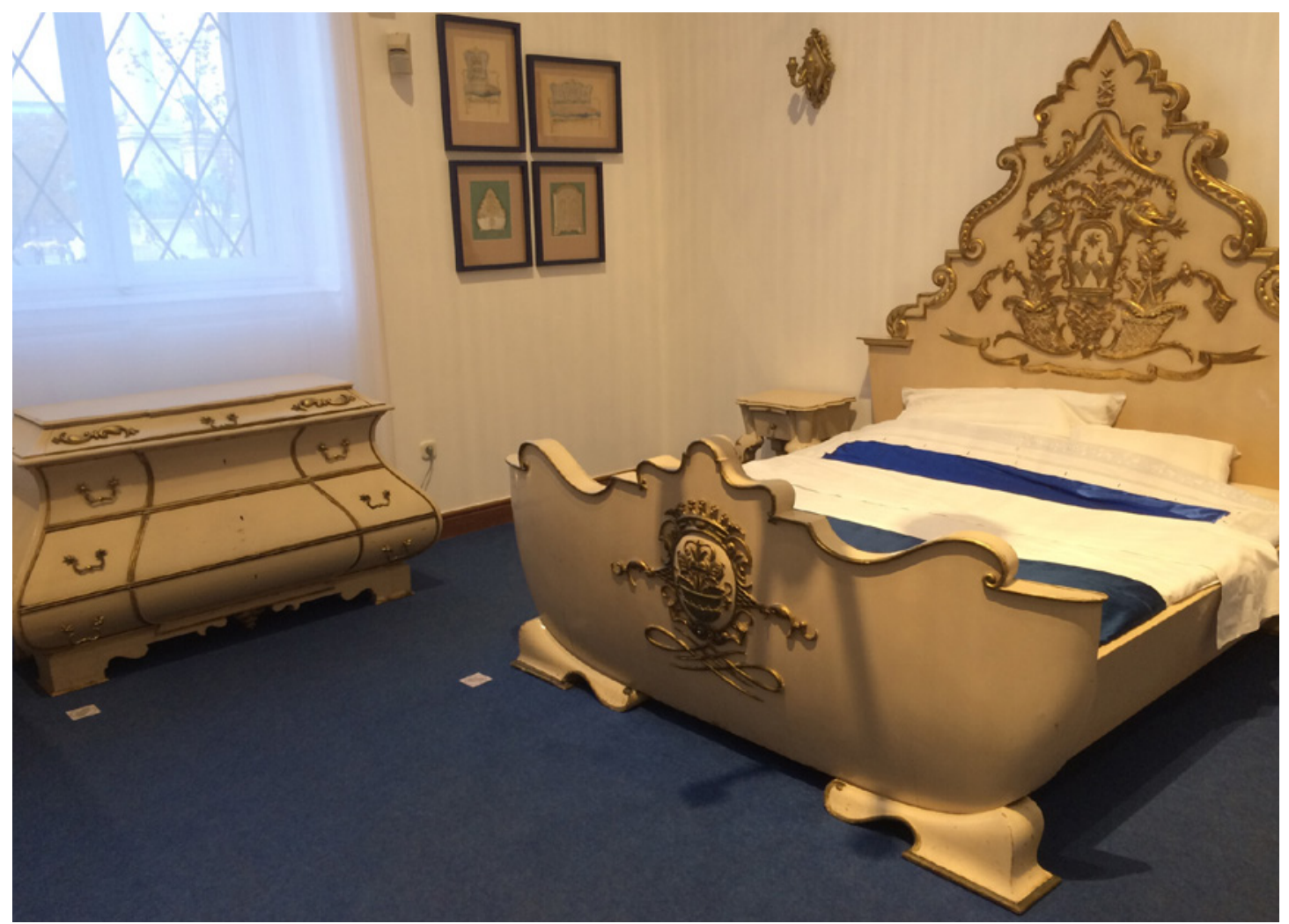

Figure 19: Lajos Kozma, bedroom suite, as displayed in exhibition 'Kozma Klasszik: a Budapesti Mühely és Lajos Kozma,' Mücsarnok, Budapest, 2018.

Photo: author. 
further east, it became even simpler and intertwined with earlier styles, which by that time had spread everywhere in the hands of the folk craftsmen. ... Baroque architecture had begun to have a local characteristic style. ... The Baroque was also absorbed into folk architecture. ${ }^{\prime 41}$ But it was not unique to Hungary, by any means.

\section{The Neo-Baroque in Central Europe}

At the same time that Kozma turned to the Baroque, or even earlier, Dagobert Peche in Vienna was producing designs for furniture, textiles, ceramics, glassware, graphics and especially metalwork and jewellery using the same decorative vocabulary. This became the dominant style of the Wiener Werkstätte in the 1920s, following Peche's appointment as director of the main Vienna workshops and their outlets at the end of the war. This was not regarded as a rejection of the pre-war, rectilinear style of Josef Hoffmann and Koloman Moser but a development or diversification of the earlier manner. Peche maintained the workshop's commitment to innovation and craftsmanship while placing greater emphasis on ornament as opposed to utility. He also departed from the earlier pre-occupation with totalizing interior design or Gesamtkunstwerk, in favour of a multiplicity of decorative objects related through their common design vocabulary. For this, Peche looked back to the Baroque and Rococo of the seventeenth and eighteenth centuries, a golden age of the Habsburgs, while deliberately rejecting the monumental Neo-Baroque of the later nineteenth century. In contrast to the grandiose public buildings and formal interiors of the Ringstrasse, Peche mined the Baroque for motifs to create a range of decorative objects and patterns that domesticated and feminized the style. Indeed, when Peche died in 1923, Hoffmann declared that he was 'Austria's greatest genius in ornamentation since the days of the Baroque ... All of Germany has experienced a new stylistic epoch thanks to Peche's designs.' ${ }^{42}$

Peche may have led the way, but he was not alone in following this route. Looking to contemporary work in Austria, Germany, Poland and Czechoslovakia throughout the 1920s, one can find a number of prominent architect-designers, such as Eduard Pfeiffer in Munich, Fritz August Breuhaus in Bonn and Dusseldorf, Emanuel Josef Margold in Darmstadt, Wilhelm Foltin, Ernst Lichtblau, and Otto Prutscher in Vienna, and many others in the pages of InnenDekoration, all of whom turned to the Baroque as part of a new repertoire of forms for the bourgeois interior.

The group that engaged in the most innovative revival of the Baroque in the years leading up to, and after the First World War were the Czech Cubists, although this is not always given prominence in the literature. There is, however, no doubt about the presence of folk-Baroque as a key source in both their writings and designs. ${ }^{43}$ In 'The Prism and the Pyramid' (1911) Pavel

41) Samu Benkő, 'Őszi beszélgetés Kós Károllyal Erdély köveiről’ [An Autumn Discussion with Károly Kós about the 'Stones of Transylvania], Utunk Ėvkönyv, Kolozsvár/Cluj, 1977, 119-125; quoted in Gall, Kós Károly mühelye (as in n. 1), 301.

42) Peter Noever, 'Introduction,' P. Noever, ed., Dagobert Peche and the Wiener Werkstatte, New Haven: Yale University Press, 2002

43) The Baroque is frequently invoked in Czech and Slovak discussions of a 'national style' in architecture and design during the final decades of the nineteenth century and the first three decades of the twentieth. See Alena Janatková, Barockrezeption zwischen Historismus und Moderne. Die Architekturdiskussion in Prag 1890-1914, Zürich: GTA 
Janák made the link to vernacular sources of the Baroque quite explicit: 'Our local architecture has been determined by two large European architectural families: Southern Antiquity and that of Northern Christianity. ... [The Southern spirit] developed its full potential above all in the Baroque, a period again controlled by abstraction. It was typical of our national character. ${ }^{34}$ The link is clearly indicated in the House of Dr. Fára at Pelhřimov. This was not a new building in 1912-13 when Janák redesigned the facade; it was previously an inn dating back to the eighteenth century, so the overall design was largely defined by an existing plan and streetscape. Nevertheless, the finished ensemble indicates how effectively Cubist planar faceting overlays the forms and details of the pre-existing vernacular, i.e., the folk-Baroque. On new buildings, such as the Kovařovic Villa by Josef Chochol (1912-13) or the Bohdaneč spa pavilion (1916) by Josef Gočár, the architects preserved the essential repertoire of forms, details and disposition of elements around a central axis that was established by the seventeenth century. Similar effects can be seen in such Rondo-Cubist buildings as the Legio Bank (1921-23, Figure 20) or the Adria Palace (1923-25) in Prague where the monumental forms and rigid geometry of the facades may suggest something modern, but there is no mistaking the use of a stylized repertoire of Baroque architectural decoration; the volutes, capitals and cartouches may be simplified and exaggerated in scale, but they still carry the echo and meaning of their sources. Czech Cubism before and after the war was a multifarious movement with many sources, but the historic Baroque references are a key element in both its formation and its reception.

The Baroque sources are less explicit, but they are even more deeply embedded in the furniture designed by the Czech Cubists. Some pieces emphasize the faceting of form that can be linked to both Cubism and to Janák's theories of the crystal, but the massive scale and solidity of many items recall seventeenth- and eighteenth-century prototypes. The materials used (generally expensive dark woods and veneers with rich graining) and the cabinetmaking techniques also hark back to historic models associated with the grand settings of the palace and country manor house. However, it is in their use or deployment within the home that their traditional and historic character is most evident. Unlike modernist interiors of the same date, Czech Cubist furniture was rarely intended to re-orientate the domestic space. Generally, the bulky tables and sideboards reaffirmed the role of furniture as items of display or conspicuous wealth, rather than altering the patterns of domestic life. This is especially true of the largescale pieces that were produced in the newly created Czechoslovakia after the war - pieces such as the sideboard designed by Gočár in 1921 for the villa of textile magnate Josef Sochor at Dvůr Králové in north-eastern Bohemia, where the historical references are quite explicit (Figure 21). Far from opening up the space to more flexible and informal activities, these pieces solidify traditional patterns of room use and function.

These aspects were uppermost in the mind of the avant-garde designer Karel Teige when in 1929 he published a withering attack on Cubist architecture as 'a return to Baroque thinking and possibly even (because of its dramatic qualities) to Baroque form. ${ }^{45}$ For

Verlag, 2000, and Vendula Hnídková, ed., Národni styl: Kultura a politika [National Style: Culture and Politics], Prague: Academy of Arts, Architecture and Design, 2013, 154.

44) Reprinted in Timothy Benson and Éva Forgács, eds, Between Worlds: A Sourcebook of Central European AvantGardes, Cambridge Mass.: MIT Press, 2002, 86.

45) Karel Teige, Modern Architecture in Czechoslovakia and Other Writings, trans. Irena Murray and David Britt, Los Angeles: Getty Research Institute, 2000, 143. 

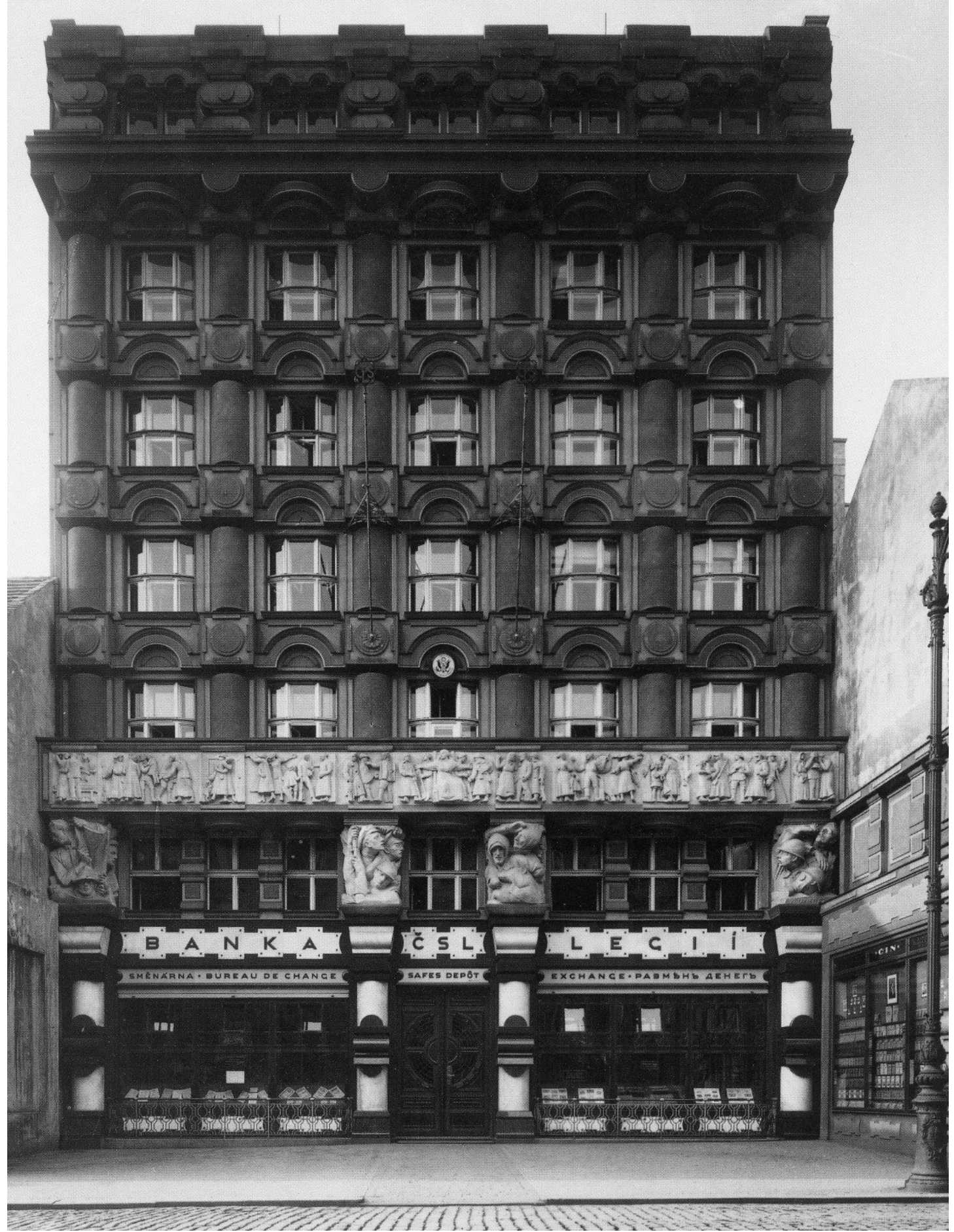

Figure 20: Josef Gočár, Legio Bank, Prague, 1923.

Source: Prázdné domy. 


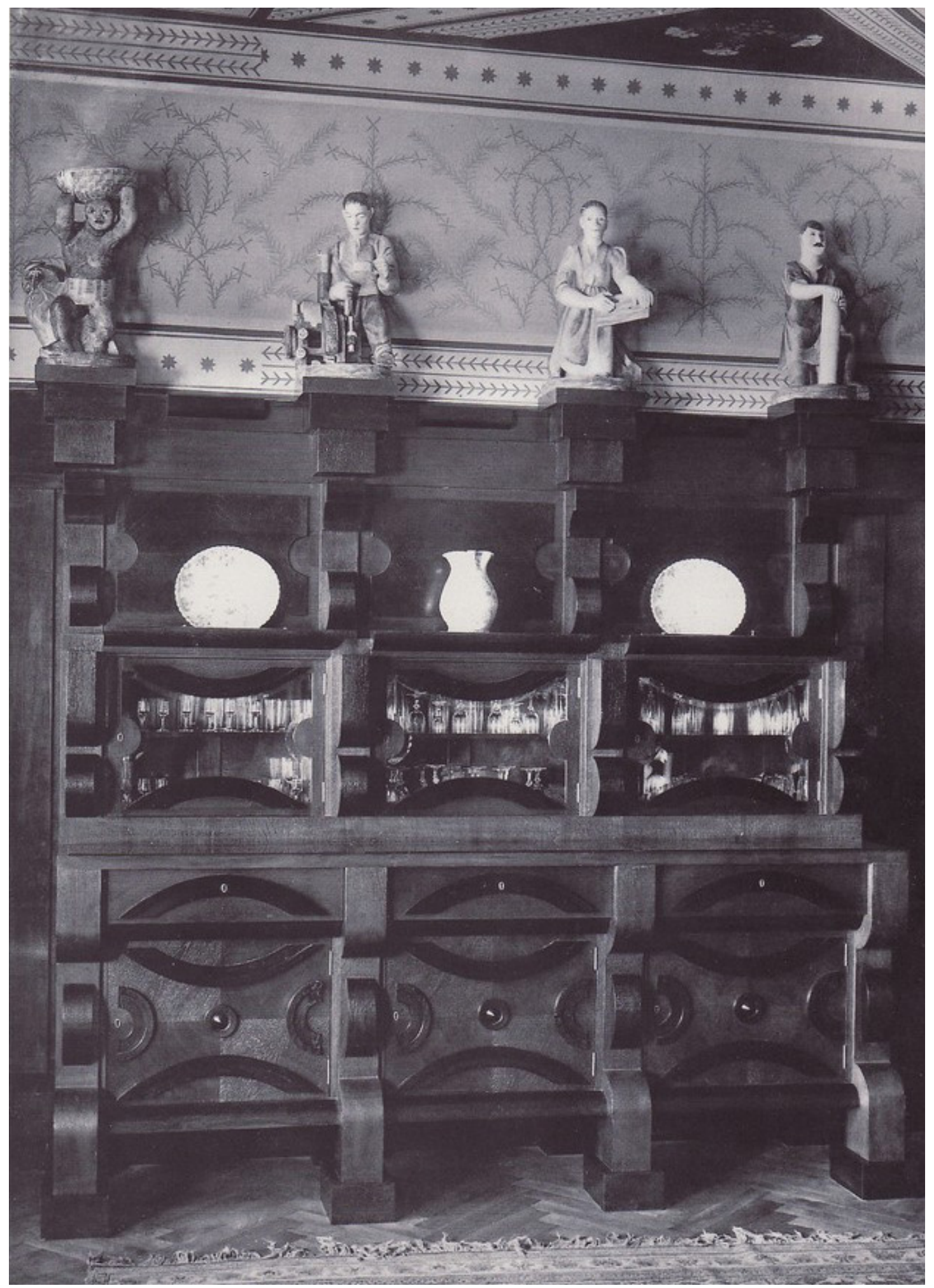

Figure 21: Josef Gočár, Sideboard for Josef Sochor at Dvůr Králové, 1921. Source: period photograph. 
Teige, 'The perpetual use of oblique deformed planes, the violation of the material and the disregard for the construction and function were but the expressions of a false Baroque spiritualism resurrected by the Secession. ${ }^{46} \mathrm{He}$ was no less scathing about the furniture: 'Thus, the dynamic architecture of Czech Cubism dwindled to nothing but a chaotic play of forms affixed to some lamp, impractical sideboard, or useless desk - an armchair in which we couldn't sit without keeling over, a vase or goblet that toppled when touched. ... Their massive furniture, dynamically multidirectional, is full of heavy-handed, pathetic, and oppressive materiality. ${ }^{37}$

\section{Neo-Baroque society in Hungary}

It should be apparent from these examples that the Neo-Baroque can be traced through a range of sources testifying to its presence, if not its precise meaning, in intellectual and aesthetic discourse. Furthermore, there can be little doubt that the term and its historical interpretation was undergoing something of a revision in the early years of the twentieth century. The period before and after the First World War was when the Baroque became accepted as a serious style in the eyes of historians of the Vienna School and further afield, thus lending the style a greater degree of respectability. ${ }^{48}$ At the same time, it is questionable if this trickled down to the people who were buying 'Kozma-Baroque' bedroom suites and hall mirrors. A fuller explanation for the rise of the style in the 1920s would have to look more closely at the world view shaped by the broader social and cultural shifts of the period - the Weltanschauung, to use a term now distrusted among social historians of art and design.

What might account for its appeal to a broad public in Hungary? One factor was the emergence of the Roman Catholic church as a political force under the regency of Admiral Horthy, and the redefinition of Hungary as a narrowly Christian nation by the more assertive nationalists following the humiliation of Trianon. Baroque was the historic style of the church militant in the age of the Counter Reformation, so it struck a chord with the mood of 'Christian Hungary. ${ }^{99}$ This period also saw a renewed focus on the Hungarian aristocracy, indicating the explicitly nostalgic and retrogressive mood of the country growing out of the fanatical irredentism of the 1920s. Just such a combination of religion, politics and modernity was the focus of an influential book by the conservative political commentator Gyula Szekfü in which he first coined the term 'Neo-Baroque society.' Három nemzedék (Three Generations), first published in 1920 but revised and expanded later to take in the post-war developments, set out to trace the political ideologies and values of the Hungarian ruling class from the Reform Generation of the 1840s, symbolised by Count István Széchenyi, up to the First World War and

46) Ibid., 146.

47) Ibid., 152.

48) The key figures in the reinterpretation of Baroque architecture were Max Dvořák and especially Heinrich Wölfflin, whose book Renaissance und Barock (1888) was a landmark.

49) On the role of the Roman Catholic Church in public life in Horthy's Hungary, see Paul A. Hanebrink, In Defense of Christian Hungary: Religion, Nationalism, and Antisemitism, 1890-1944, Ithaca: Cornell University Press, 2009. See especially chapters 3 and 4 . 
post-Trianon society. ${ }^{50}$ Like most conservatives, Szekfü found the public figures of his own day lacking, and the political discourse misguided and delusional. In particular, he highlighted a tendency towards willful nostalgia and a conscious failure to acknowledge contemporary political realities. This 'Neo-Baroque society' brought the aristocratic stratum back into public life, but it was a deeply flawed class of men, penetrated by the mercantile middle classes and lacking any sense of their traditional role or national responsibilities.

Szekfü had no time for the revolutionaries of 1919, but there was a grudging respect for their commitment to an ideal and the galvanising impact this had exerted on cultural life. By now, however, the writers, artists and composers of 1919 were in exile in Vienna, Berlin, Moscow or Dessau, leaving a vacuum at least among the avant-garde. In addition, Szekfü drew attention to the failure of the clergy to uphold moral standards, alongside a compliant public prepared to 'respect authority quite generously.' In this climate, the metropolitan middle class stood behind a state led by an admiral without a navy, and balanced its illusions of a glorious history and a sense of tradition alongside a cynical collusion with the regime to maintain the benefits of the status quo:

It is also understandable from the nature of the Neo-Baroque that all this well-being is, after all, just an outward appearance, and that the people within themselves are further removed from respect for authority than ever before. This backwardness of the critical spirit then avenges itself in the fact that the person who admires the Neo-Baroque in public, persecutes the object of his adoration with evil-mouthed, murderous jokes in his private life: mocking people and situations with the help of this Viennese Baroque spirit. ${ }^{51}$

Szekfü's pessimistic view of post-Trianon politics and society has cast a pall over most analyses of the period, not least the broader assessments of Hungarian art and design of the 1920s. This has played into the classic modernist views of history that give priority to the avant-garde. In that reading, most innovative Hungarian design was produced by those forced to flee after the collapse of the Hungarian soviet republic in 1919. Even today, accounts of Hungarian architecture and design tend to feature work by Moholy-Nagy, Marcel Breuer, and Ernő Goldfinger, all of whom left Hungary before they had produced anything that might be described as mature work, while the actual design that was produced, exhibited, discussed and sold within the country during the 1920s is passed over cursorily.

The Neo-Baroque has had very mixed fortunes in the historiography of Hungarian design, with most writers tending to dismiss Kozma's turn to the Baroque as either an aberration or a compromise due to restrictions placed upon his architectural practice. Kozma's activities in the Arts Directorate of the Soviet Republic in 1919 certainly limited his professional advancement under the right-wing regime of Admiral Horthy. But the popularity of the Neo-Baroque seems also to have alienated left-leaning groups like the Association of Hungarian Engineers and Architects, who excluded Kozma from

50) Gyula Szekfü, Három nemzedék: Egy hanyatló kor története [Three Generations: the history of an epoch of decay], Budapest: Élet, 1920. A later edition of 1934, entitled Három nemzedék, és ami utána következik [Three Generations and what follows], Budapest: Királyi Magyar Egyetemi Nyomda, 1934, included a fifth chapter bringing the analysis up to date.

51) Szekfü, Három nemzedék, és ami utána következik, 420. 
membership until 1928. Even in a monographic essay, the left-wing critic Ernő Kállai (1890-1954) dismissed Kozma as an 'artist of the mercantile and financial bourgeoisie. ${ }^{52}$ Among later critics and historians one finds the persistent view that furniture and interior design could only ever be regarded as an inferior activity for a trained architect, undertaken solely because there was no building work available. In that vein, both Máté Major (1949) and Judith Koós (1975) viewed the Neo-Baroque as a 'compromise', a temporary piece of opportunism on Kozma's part until he could re-establish his architectural practice. ${ }^{53}$ For László Beke, this phase was a sign of the 'difficulties' Kozma experienced on his journey towards a full blown modernism, as if the end point (i.e. Kozma's modernist work in the 1930s) was a pre-ordained and logical conclusion to the complex and turbulent currents of the 1920s. ${ }^{54}$ Only the curators at the Museum of Applied Arts and the Kiscelli Museum, who concentrate on the decorative arts, seem prepared to accept Kozma-Baroque as a serious design movement on its own terms, expressed through a range of media including furniture and interiors, graphics and textiles. ${ }^{55}$ Among recent publications, one tendency has been to treat Kozma-Baroque as the Hungarian version of 'Art Deco,' although this is hardly a satisfactory interpretation. ${ }^{56}$ The inclusion of the Neo-Baroque within an international style defined in Paris tends to oversimplify the rich diversity of the sources and meaning of the style within Hungary, just as the merging of central European national romantic tendencies with Art Nouveau smooths out the distinctive regional meanings while serving little serious purpose other than offering a platform for promotion and tourism.

There is also a gendered dimension to this discourse. Kozma-Baroque had a brilliance and wit, a sparkling vivacity that was best seen in a light-hearted and playful treatment of historical styles rather than any larger moral purpose. In fact, it is often at its best in the decorative packaging of feminized luxury goods such as those designed for the Floris confectionery company, but also found in greetings cards, ex libris and various types of printed ephemera (Figure 22). These are not the type of designed objects upon which historians feel able to hang larger analyses of style and society, so the widespread appearance of the Neo-Baroque throughout the 1920s remains in a historical limbo: present in all the source material of the period but unacknowledged by the historians.

52) Quoted in András Ferkai, ‘Bevezető,' in Éva Horányi, ed., Kozma Lajos modern épületei, Budapest: TERC Kiadó, 2006, 13.

53) In 1926 an amnesty was granted to those who had been involved in the Soviet Republic of 1919, leading to the return of many emigres and the freeing of restrictions on those who remained in Hungary. Two years later, in 1928, Kozma was admitted to the Chamber of Architects.

54) László Beke and Zsuzsa Varga, Kozma Lajos, Budapest: Akadémiai Kiadó, 1968, 5

55) See Ėva Kiss and Hilda Horváth, Kozma Lajos, az iparmüvész (1884-1948), Budapest: Iparművészeti Múzeum, 1994; Éva Horányi, ed., Kozma Lajos modern épületei, Budapest: TERC Kiadó, 2006.

56) See Éva Horányi, Art deco és modernizmus: Lakásművészet Magyarországon, 1920-1940, catalogue to an exhibition in 1912 placing Kozma's Neo-Baroque works at the centre of the movement. 


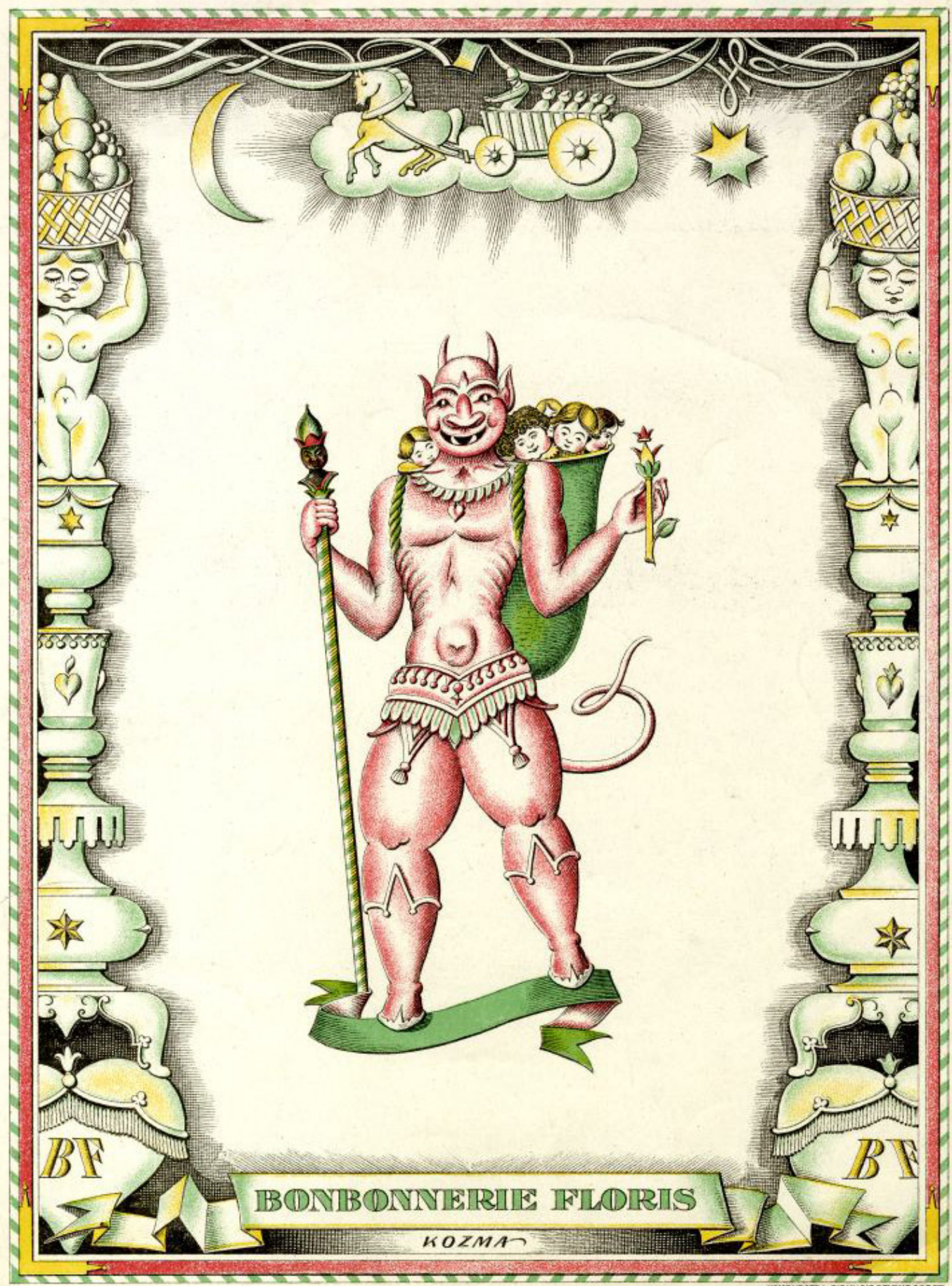

Figure 22: Lajos Kozma, Advertisement for Floris confectioners. Source: Museum of Applied Arts, Budapest. 


\section{Károly Kós after Trianon}

As mentioned earlier, Kós spent the latter part of the war in Istanbul, and he returned to a broken and volatile Hungary, soon to lose two thirds of its territory and people to the successor states. The most important, or at least the most personal, loss was Transylvania, which became part of Romania. Transylvania was not only the substantial territory in eastern Hungary, but it had been regarded for some time as the heartland of Hungarian peasant culture and therefore, for Kós's generation, the repository of the true essence of Magyar history and identity. It was held to be the only place with an unbroken link to the pre-Ottoman Hungary of Matthias Corvinus stretching right back to the early Middle Ages, when the seven Magyar tribes had first occupied the Danube basin. This was the foundation myth of Hungarian legitimacy, just as other ethnic groups in the region, not least the Romanians, upheld and propagated their own foundation myths. By the time of the census in 1910, it was apparent that the largest single ethnic or linguistic group in Transylvania was Romanian or 'Vlach.' This simple calculation would determine the borders set by the victorious Entente powers at the Paris peace conference of 1918-20. Kós returned, therefore, to a situation in which the community into which he was born and which he had championed through his design work - one that had enjoyed hegemony under the Empire - was now an embattled minority within the territory that they took for granted as their homeland.

Trained in the reform tradition of Ruskin and Morris, where design and architecture could never be seen as something distinct from society, nor separate from the demands of morality and social responsibility, Kós was faced with a dilemma. The community that he was so proud to belong to, the wellspring of his ideas about history, culture, and identity, was facing marginalization or, at least, a loss of that identity. In response, and despite offers of positions in Budapest, Kós chose to settle in Transylvania and attempt a dual role of architect-designer and all-round defender of the culture of the Hungarian and Szekler communities, although he must have known that the opportunities he had enjoyed in the pre-war period would not be extended under the regime based in Bucharest. A case has been made that these reduced circumstances forced Kós to become more environmentally conscious in the 1920s and 30s. ${ }^{57}$ In the absence of major building commissions, he worked on a range of modest projects, such as farm buildings, animal pens, home and church extensions, which served the needs of his community in a practical way. Moreover, these simple works were often in a stripped down, modern formal language without the overt references to the vernacular that characterized his pre-war buildings. Nevertheless, one cannot avoid the fact that the environmental argument, which only came to the fore in the 1990s when the concept of eco-friendly architecture gained currency, was more a matter of necessity than choice. Kós was distrustful of the internationalism at the heart of the Modern Movement to such an extent that when in 1930 he saw designs by Eliel Saarinen, by this time resident in the USA, who had moved irrevocably from a National Romantic style to a mature modernist manner, Kós declared that the work was anonymous and that he no longer recognized his friend. ${ }^{58}$

57) See Gall, Kós Károly mühelye (as in n. 1), 85-89.

58) Károly Kós, 'Saarinen Eliel, a legnagyobb finn építőművész' [Eliel Saarinen, The Greatest Finnish Architect], Pásztortüz, 26:2, 1940, 86-90. 
By settling in Transylvania, Kós was, in effect, sacrificing his career as architect-designer for a special role as protector of cultural history and identity. To this end, he was responsible for establishing a political party, The Transylvanian Peoples' Party, a cultural association, the Transylvanian Guild of Fine Arts (Erdélyi Szépmíves Céh), a publishing house to produce books on Transylvanian themes, and Erdélyi Helikon (The Transylvanian Helicon), the first of several journals based in Cluj to promote research and interest in the Hungarian heritage of the region. It is worth noting the name of the main cultural organization: Transylvanian Guild of Fine Arts. Kós was still thinking in terms that were familiar to followers of William Morris and Charles Robert Ashbee, who felt there was a way through the appalling conditions and social alienation of industrial capitalism, by seeking to bring back the engagement with work and materials that they felt was characteristic of medieval guilds. In this case we might regard Kós as someone who could envisage restoring a certain balance to the current situation through the revival of guild socialism; only in this case, it might be a form of 'guild nationalism.' There is a certain poignancy in the impassioned plea he made in a Sunday newspaper regarding the task in hand:

Someone may ask, why are you telling us all this? Don't you realise it is 1923, that we are in Transylvania, and we have neither a Ruskin, nor a Morris, nor or an Ashbee, and our people are not English. Nor do we have anonymous patrons who are able to dedicate large sums of money to communal purposes, work co-operatives, or to artistic goals in general. ... We need art, and we need artistic works, just as we need the other products of culture. And because we need them, we must produce them. We have our past; our people live, and their folk art lives too. All we need is a Ruskin, a Morris, and an Ashbee. ${ }^{59}$

Kós followed his own appeal, turning to the English model of the private press which he established under the colophon of his home, Crow Castle, rising up out of the pages of an open book (Figure 23). In the absence of any substantial architectural commissions, this press became his most significant achievement in the 1920s. In a series of books, some of which are still available in popular trade editions, he celebrated the vernacular architecture and folk traditions of the region. The finest of his books has the evocative title, Erdély Kovei (The Stones of Transylvania); the reference to Ruskin was unmistakable. For the illustrations he employed the most basic printing method, the linocut. Not only was this practical, in that he could work on these with minimal equipment, but the very simplicity (even crudeness) of the technique seemed perfectly suited to the subject matter. It also allowed him to experiment with bold reductions of form and colour in the depiction of a range of building types, from peasant cottages to castles (Figure 24).

Interesting and attractive as they are, however, one must ask whether they are more than a form of nostalgic romanticism; keepsakes for a beleaguered society that was getting moral sustenance through collectible, limited edition books of their built heritage. The private press movement was at its height in the 1920s, especially in the English-speaking world and in Germany, just as the Livre d'Artiste was thriving among the avant-garde in France. But Kós's work seems to have less to do with that form of elite modern collectible than his

59) Károly Kós, ‘Kézműves Céh’ [The Guild of Handicraft], Vasárnapi Újság, 1 July, 1923. 


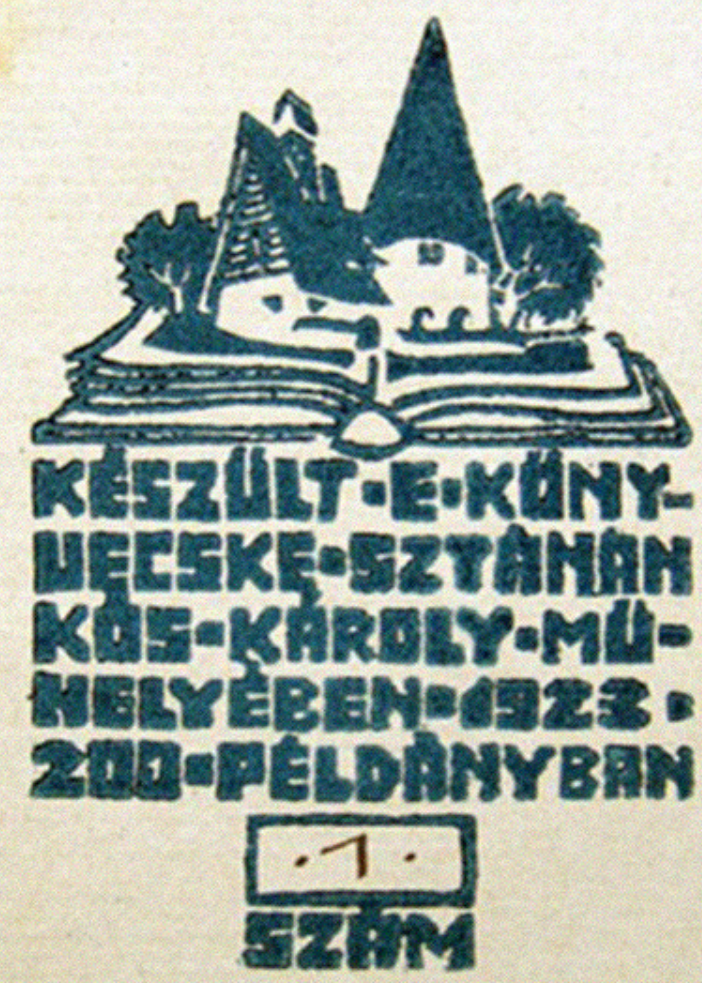

Figure 23: Károly Kós, colophon of private press at Crow Castle, 1923.

Source: author's photo.

personal revival of the principles of the Arts \& Crafts movement. This indicates that Kós was thrown back onto the set of values that had formed his taste and practice in the pre-war years, when Ruskin, Morris, Ashbee and Walter Crane were still vital forces in the discourse on contemporary design and national identity; but these Victorian prophets seem somewhat anachronistic in the restructured Central Europe of the 1920s. Kós himself had doubts, asking in the preface to his 1929 book Erdély (Transylvania), 'Can this closed Transylvanian land have the spiritual power to know the different, or even opposing, voices of other human societies in consonant harmony? Is there a Transylvanian culture at all, and if so, for what reason?'60

60) K. Kós, Erdély, Kolozsvár: Erdély Szépmíves Céh, 1929 


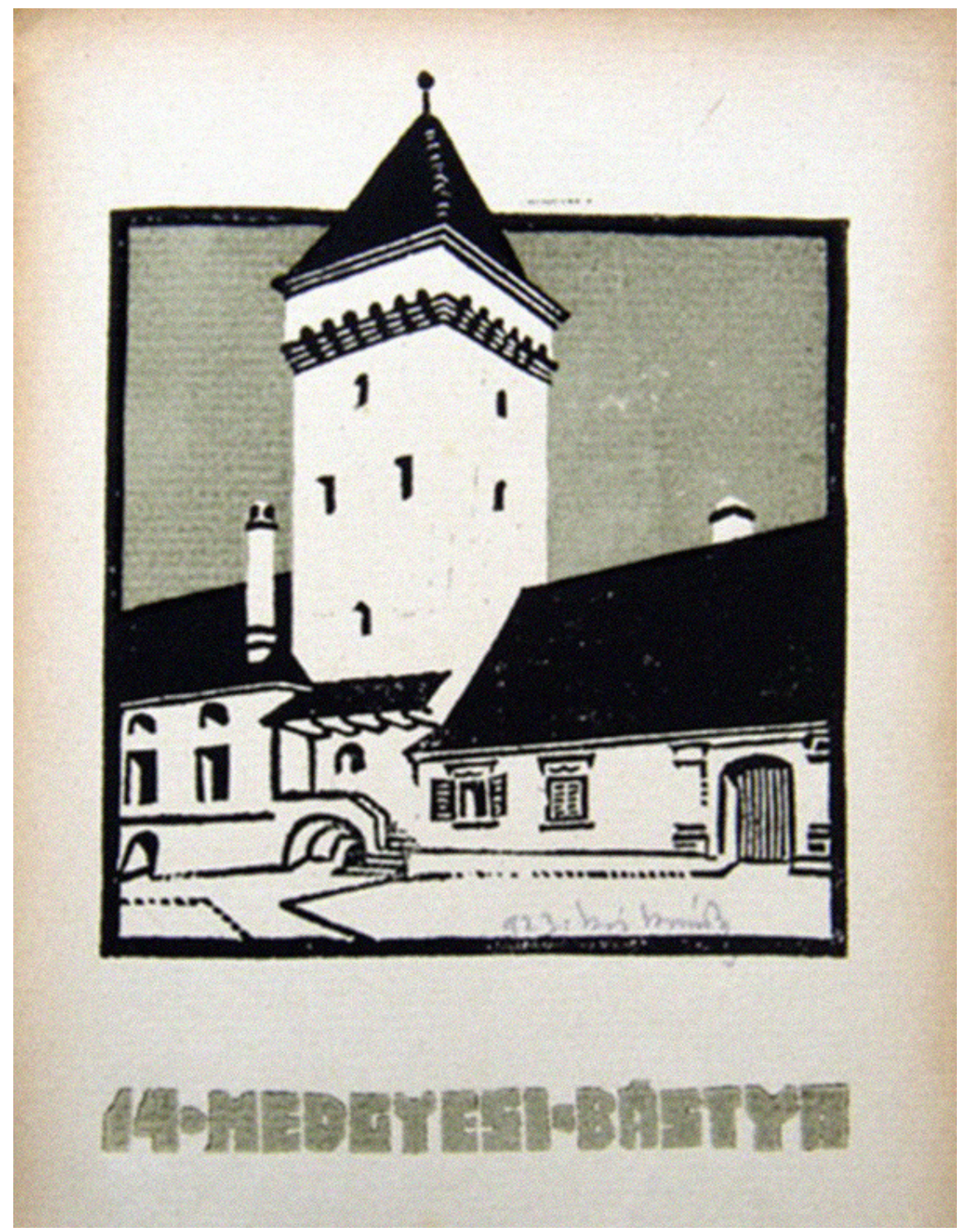

Figure 24: Károly Kós, 'Medges Bastion' illustration to Erdély kövei

[The Stones of Transylvania], Linocut, 1923.

Source: author's photo.

\section{Conclusion}

This article has indicated some of the ways in which two leading architect-designers responded to the changed political and cultural environment at the end of the First World War. By its very nature, design is a social activity, in that it requires the participation of the designer, the manufacturer or builder, the client, and a range of other related actors. In that context, the work of the architect-designer is often affected directly by changes in the economic and political climate. This is certainly true of the two figures discussed above. Kós, the most successful Hungarian architect of his generation in the years leading up to the First World War, witnessed 
the disintegration of the economic and political base that supported his early career. Upholding the reformist ideals of Ruskin, Morris and Ashbee, in which the architect-designer is expected to assume an almost priestly role, he could not renounce the moral responsibilities as custodian of the cultural identity of the much-diminished postwar Hungarian community in Transylvania.

Whatever his innate talent as an architect-designer, Kós's early success was dependent on the considerable political and economic resources, and the prevailing cultural climate, of Greater Hungary. This enabled him to develop a programme of architectural reform based on the revival of vernacular design and craft as part of a nation-building project. Once the scaffolding of his earlier career had been removed and his beleaguered community was exposed to new political realities, Kós could not repudiate his earlier values, but instead redoubled his commitment to the principles that had informed his earlier work, even at the expense of his architectural career. By contrast, Kozma, who had come to maturity in the same reformist environment of pre-War Budapest, responded to the changed cultural landscape by confirming his commitment to the new and commercial manner of the Neo-Baroque, for which he became a standard bearer throughout the 1920 s.

Beyond recounting the contrasted careers of these two figures, however, this article also raises certain questions about the design culture of the 1920s and the ways in which it has been interpreted. In blunt terms, it asks: what is the nature and status of the Neo-Baroque in Central Europe, and why has it been marginalised or excluded from most histories of design? The first problem is the apparent lack of any larger theoretical or moral position in the Hungarian Neo-Baroque. The 1920s was the great period of modernist discourse, but Kozma and most of his supporters rarely felt motivated to justify their line of work beyond their recognition of its internal coherence and broader appeal to the market. The Neo-Baroque did not come armed with any higher moral or social theory in its arsenal.

A more obvious problem has been the position of this historicist style in the grand narratives of twentieth century design. The Neo-Baroque cannot easily be accommodated within the model of teleological development first advocated in Nikolaus Pevsner's classic Pioneers of the Modern Movement, which traced a singular line of descent from William Morris to Walter Gropius and the Bauhaus. ${ }^{61}$ One might have expected this narrative to have fallen away somewhat after more than 50 years during which the modernist reading of history has been repeatedly challenged, but the values of essentialism, formalism, internationalism, and moral seriousness - what the Kozma scholar Eva Kiss describes as 'the puritan thirst of the twentieth century' - are still taken to be defining characteristics of significant design developments. ${ }^{62}$ Kozma's emphasis on the decorative and the playful, or on qualities like irony and wit seem more suited to a postmodern sensibility, but this has not carved out a space for the NeoBaroque in most synthetic histories of design. ${ }^{63}$

61) Nikolaus Pevsner, Pioneers of the Modern Movement: from William Morris to Walter Gropius, London: Faber, 1936, and several later editions.

62) Eva Kiss, 'Népművészet és dekorativitás: A fiatal Kozma Lajos tulipános tervei' [Folk art and decorativeness: Tulip designs by the young Lajos Kozma], Magyar Iparmüvészet, 17:7, 2018, 23.

63) The term 'Neo-Baroque' has gained currency in film and literary studies, particularly in relation to the visual culture forms of the 1980s that display 'a loss of entirety, totality, and system in favor of instability, polydimensionality, and change.' See Omar Calabrese, Neo-Baroque: A Sign of the Times, Princeton NJ.: Princeton University Press, 1992, xii. In the same context it is taken to mean 'Postmodernism.' 
A further problem arises from the very words used throughout the literature to describe the Neo-Baroque: 'decorative', 'playful', 'ironic', 'entertaining'. These are all gendered terms with feminine connotations. In a complement to the modernist argument, they are qualities or attributes that are widely felt to have less substance than the more earnest movements promoting function and morality in design. Kozma-Baroque is an unashamedly light-hearted, witty and playful manner whose originality lies in the revitalisation of a pre-existing historic repertoire, often undermining its more pompous, aristocratic origins in favour of a humorous play of colour and scale that appeals to the educated, middle class consumer. This serves to remind us of the extent to which questions of historical importance are still shaped by traditional assumptions prioritising a combination of modernist, masculine and utilitarian concerns.

A different set of problems arises when one asks whether the Neo-Baroque might be interpreted as a regional expression of 'Art Deco'? From the examples cited above, it should be clear that the Neo-Baroque was a rich and complex movement that, while enjoying some degree of breadth across Central and Eastern Europe, also had specific iterations and meanings in separate countries. The 'Cubist Baroque' that would come to dominate in Czechoslovakia is quite different from the Kozma-Baroque of Hungary, although they share many features in terms of their decorative vocabulary, function and the ways in which furniture was deployed in the domestic interior. Since it appeared in mature form by 1920, and simultaneously in several countries, it seems misleading and possibly anachronistic to fold the entire movement into a broad stylistic label like 'Art Deco.'

Finally, can the Neo-Baroque be seen as the expression of a 'decadent' and 'misguided' society, as Gyula Szekfü proposed with regard to the early Horthy era in Hungary? This raises a major methodological question: to what extent can the visual arts be taken as an index of society, and therefore a manifestation of the health or otherwise of a particular culture. This linking of social morality with aesthetics has a long history but it seems to be a conceptual analogy that owes more to speculative philosophizing than the practice of cultural history. ${ }^{64}$ As such, it remains a shadowy assumption that can be invoked when convenient rather than a means of interpreting the design and material culture of any period or society. In 1934, when Szekfü coined the term 'Neo-Baroque society', there was more to play for, and the concept played a useful role in his critique of modern Hungarian politics. As such, Three Generations is an important primary source but to take it at face value is merely to repeat Szekfü's prejudices and re-join his conservative attack on modernity. There is, however, a nagging sensation that Szekfü may have put his finger on something when he identified an underlying hypocrisy in Hungarian society under Admiral Horthy, or at least a failure to reconcile certain contradictions: the re-emergence of an aristocracy that had lost any true meaning; the heightened role of a Catholic Church that lacked moral leadership; the continued belief in the re-establishment of Greater Hungary in the face of a realigned map of Central Europe. Might there be something here to explain the taste for a style in domestic interior design that offered a playful reinterpretation of history for a cynical middle class who, while recognising the contradictions, chose to support the regime which assured their continuing prosperity?

64) The key figure is Lord Shaftesbury whose Characteristicks of Men, Manners, Opinions, Times (1711) became a touchstone for a discourse carried on by Baumgarten, Hume, Kant, Burke and many others. 
There can be no question about the economic, political and social catastrophe that postTrianon Hungary experienced - possibly the most turbulent and dramatic phase in its history. In view of that, there is more to be said about the effect of these experiences, particularly in Budapest but throughout the country. Furthermore, this should be developed to consider the broader cultural values that were instituted in the period of stability under Horthy in the 1920s and 30s. That is a major project that cannot be undertaken here. Instead, it seems safer to make the more modest claim that 'Kozma-Baroque' provided sufficient support and validation to an embattled society for which the grand claims of the Transylvanian vernacular with its sense of ethnic destiny were no longer valid or meaningful. A full analysis of the history and meaning of the Neo-Baroque, however, remains to be written. 
